\title{
Emulsifying peptides from potato protein predicted by bioinformatics: Stabilization of fish oil-in-water emulsions
}

García Moreno, Pedro Jesús; Jacobsen, Charlotte; Marcatili, Paolo; Gregersen, Simon; Overgaard, Michael T.; Andersen, Mogens L.; Sørensen, Ann-Dorit Moltke ; Hansen, Egon Bech

\section{Published in:}

Food Hydrocolloids

Link to article, DOI:

10.1016/j.foodhyd.2019.105529

Publication date:

2020

Document Version

Peer reviewed version

Link back to DTU Orbit

Citation (APA):

García Moreno, P. J., Jacobsen, C., Marcatili, P., Gregersen, S., Overgaard, M. T., Andersen, M. L., Sørensen, A-D. M., \& Hansen, E. B. (2020). Emulsifying peptides from potato protein predicted by bioinformatics:

Stabilization of fish oil-in-water emulsions. Food Hydrocolloids, 101, [105529].

https://doi.org/10.1016/j.foodhyd.2019.105529

\section{General rights}

Copyright and moral rights for the publications made accessible in the public portal are retained by the authors and/or other copyright owners and it is a condition of accessing publications that users recognise and abide by the legal requirements associated with these rights.

- Users may download and print one copy of any publication from the public portal for the purpose of private study or research.

- You may not further distribute the material or use it for any profit-making activity or commercial gain

- You may freely distribute the URL identifying the publication in the public portal 


\section{Journal Pre-proof}

Emulsifying peptides from potato protein predicted by bioinformatics: Stabilization of fish oil-in-water emulsions

Pedro J. García-Moreno, Charlotte Jacobsen, Paolo Marcatili, Simon Gregersen, Michael T. Overgaard, Mogens L. Andersen, Ann-Dorit M. Sørensen, Egon B. Hansen

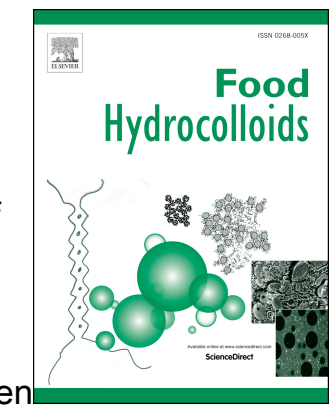

PII:

S0268-005X(19)30933-6

DOI:

https://doi.org/10.1016/j.foodhyd.2019.105529

Reference:

FOOHYD 105529

To appear in: Food Hydrocolloids

Received Date: 3 May 2019

Revised Date: 16 October 2019

Accepted Date: 18 November 2019

Please cite this article as: García-Moreno, P.J., Jacobsen, C., Marcatili, P., Gregersen, S., Overgaard, M.T., Andersen, M.L., Sørensen, A.-D.M., Hansen, E.B., Emulsifying peptides from potato protein predicted by bioinformatics: Stabilization of fish oil-in-water emulsions, Food Hydrocolloids (2019), doi: https://doi.org/10.1016/j.foodhyd.2019.105529.

This is a PDF file of an article that has undergone enhancements after acceptance, such as the addition of a cover page and metadata, and formatting for readability, but it is not yet the definitive version of record. This version will undergo additional copyediting, typesetting and review before it is published in its final form, but we are providing this version to give early visibility of the article. Please note that, during the production process, errors may be discovered which could affect the content, and all legal disclaimers that apply to the journal pertain.

(C) 2019 Published by Elsevier Ltd. 


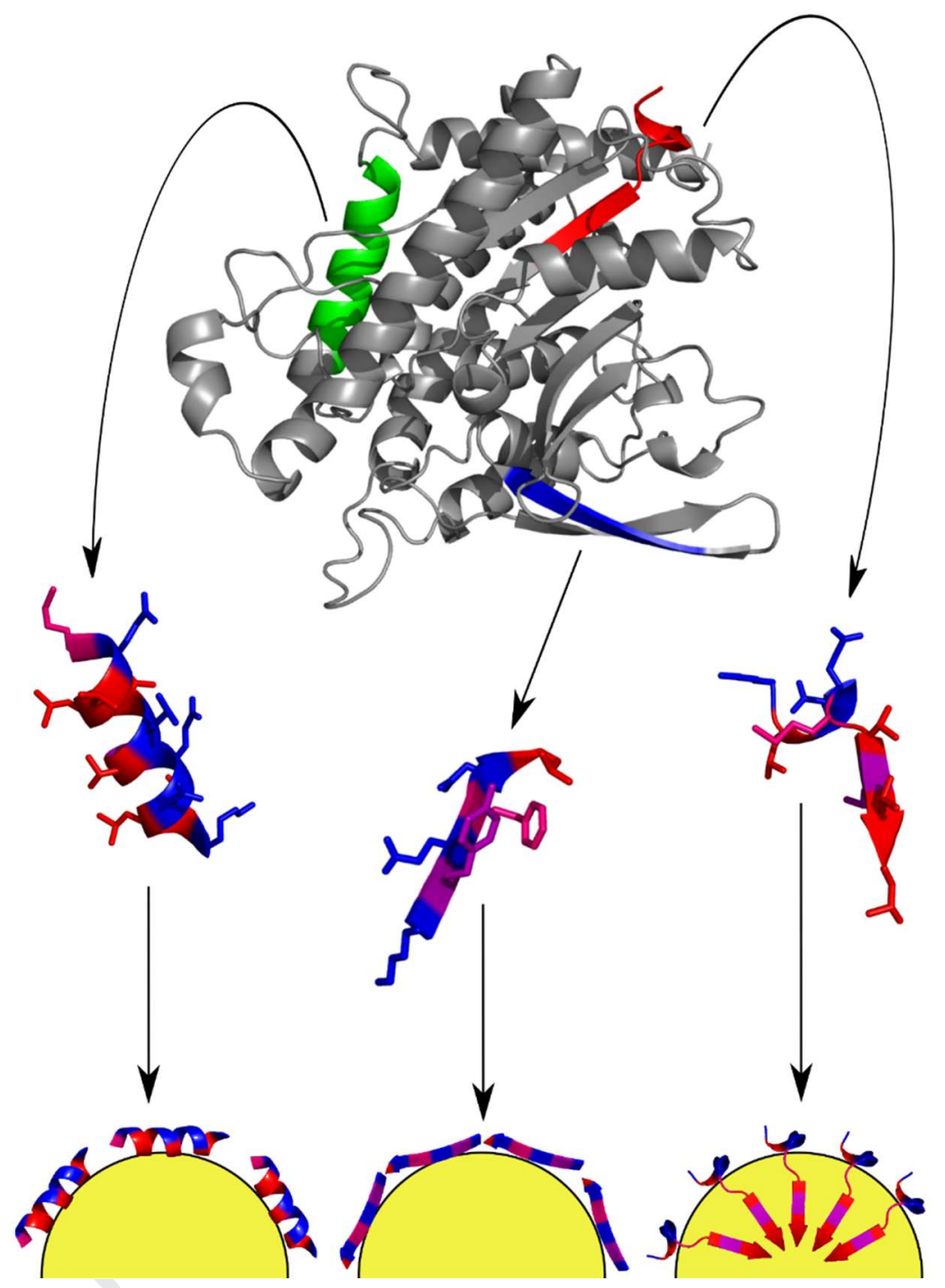




\section{Emulsifying peptides from potato protein predicted by}

\section{2 bioinformatics: stabilization of fish oil-in-water emulsions}

3 Pedro J. García-Moreno ${ }^{1,2 *}$, Charlotte Jacobsen ${ }^{1}$, Paolo Marcatili ${ }^{3}$, Simon Gregersen ${ }^{4}$,

4 Michael T. Overgaard ${ }^{4}$, Mogens L. Andersen ${ }^{5}$, Ann-Dorit M. Sørensen ${ }^{1}$, Egon B. Hansen ${ }^{1}$

5

$6 \quad{ }^{1}$ National Food Institute, Technical University of Denmark, Denmark

$7 \quad{ }^{2}$ Department of Chemical Engineering, University of Granada, Spain

$8{ }^{3}$ Department of Bio and Health Informatics, Technical University of Denmark, Denmark

$9{ }^{4}$ Department of Chemistry and Bioscience, Aalborg University, Denmark

$10 \quad{ }^{5}$ Department of Food Science, University of Copenhagen, Denmark

11 ABSTRACT

12 This work investigated the use of bioinformatics to predict emulsifying peptides embedded in 13 patatin proteins from potato (Solanum tuberosum). Six peptides (23-29 amino acids) with potentially different predominant structure at the oil/water interface (e.g. $\alpha$-helix, $\beta$-strand or unordered) were identified within patatin sequences. The interfacial tension between peptides solutions and fish oil as well as the physical and oxidative stability of $5 \mathrm{wt} \%$ fish oil-in-water emulsions $(\mathrm{pH}$ 7) stabilized with synthetic predicted peptides were evaluated. The peptides predicted to have lower amphiphilic score $(\alpha 1$ and $\alpha 2)$ led to emulsions with creaming after production and with low oxidative stability. On the other hand, a half hydrophobic and half hydrophilic peptide $(\gamma 1)$, which was predicted to have the highest amphiphilic score, showed a superior ability to reduce interfacial tension (even when compared to casein). $\gamma 1$-stabilized emulsion was physically stable during storage $\left(48 \mathrm{~h}\right.$ at $\left.50{ }^{\circ} \mathrm{C}\right)$ and presented the lowest droplet size $\left(\mathrm{D}_{4,3}=0.518 \pm 0.011 \mu \mathrm{m}\right)$. Electron spin resonance (ESR) and Oxygraph results indicated that the type of synthetic peptide used also affected the oxidative stability of fish oil-in-water emulsions differently. Therefore, this study shows the potential of using

\footnotetext{
*Corresponding author: pejeg@food.dtu.dk
} 
bioinformatics to predict emulsifying peptides, reducing time and cost of extensive screening hydrolysis processes.

Keywords: omega-3, physical stability, oxidative stability, interfacial tension, electron spin resonance, Oxygraph

\section{INTRODUCTION}

Potato (Solanum tuberosum) is the world's fourth most important food crop, after maize, wheat and rice (FAO, 2008). Potatoes, apart from being used directly as a primary food source, are widely employed in Europe for extraction of starch since $10-18 \%$ of the total weight is starch (Grommers \& van der Krogt, 2009). In the last decade, extraction of protein from side-streams in the potato starch industry has gained increasing interest due to their nutritional and functional properties (e.g. emulsifying, foaming and antioxidant) (Alting, Pouvreau, Giuseppin, \& van Nieuwenhuijzen, 2011).

Potato protein (which represent $1-2 \%$ of the total potato weight depending on cultivar) is isolated from raw potato fruit juice, which is obtained after rasping and extraction of starch and fiber from the potatoes (Alting, Pouvreau, Giuseppin, \& van Nieuwenhuijzen, 2011). Proteins contained in the potato juice are typically divided into three groups: i) patatins (up to $40 \%$ ) with a molecular weight of $39-43 \mathrm{kDa}$, ii) protease inhibitors (up to $50 \%$ ) with a molecular weight of 4.3-20.6 kDa, and iii) other proteins such as enzymes involved in starch synthesis, lipoxygenase and polyphenol oxidase (Schmidt et al., 2018; Alting et al., 2011; Pouvreau et al., 2001). Many of the highly abundant potato proteins have been shown to be located in vacuoles serving as storage proteins (Jørgensen, Stensballe, Welinder, 2011), but the specific protein composition and their abundance in potato tubers depend greatly on the cultivar (Jørgensen, Welinder, Bauw, 2006). Previous studies have reported emulsifying, foaming and antioxidant properties of both crude potato protein isolates as well as patatin and 
protease inhibitors fractions (Schmidt et al., 2018; Van Koningsveld et al., 2006; Romero, et al., 2011; Sun, Jiang, \& Wei, 2013; Liu, Han, Lee, Hsu, \& Hou, 2003).

Gentle methods, such as ethanol precipitation (Van Koningsveld et al., 2006) or initial anion exchange (IEX) followed by hydrophobic interaction chromatography (HIC) (Schmidt et al., 2018), have been developed to isolate proteins from potato juice with reduced protein denaturation compared the classical heat-acid precipitation method. Nevertheless, considerably lower yields are obtained when compared to the traditional method, which yields a $99 \%$ recovery of (denatured) protein (Schmidt, 2016). In order to increase its solubility as well as emulsifying and antioxidant properties, enzymatic hydrolysis of denatured potato protein, which increases the exposure of reactive amino acid side chains and/or hydrophobic patches, has been applied (Cheng, Xiong, \& Chen, 2010; Wang \& Xiong, 2005). The latter is required to shift the application of potato protein from feed to food, leading to high-added value ingredients (e.g. emulsifier/antioxidants).

Previous studies have followed the classical approach of digesting potato protein with different proteases (e.g. subtilisin, pepsin, pancreatin) to various degrees of hydrolysis, testing the emulsifying/antioxidant properties of the hydrolysates, and lastly attempting to identify the bioactive peptides (the latter only for antioxidant peptides) (Udenigwe, Udechukwu, Yiridoe, Gibson \& Gong, 2016; Cheng, Xiong, \& Chen, 2010; Cheng, Chen, \& Xiong, 2010). Alternatively, bioinformatics tools allow the prediction and identification of embedded functional/bioactive peptides, which can be released at specific hydrolysis conditions, reducing time and costs for extensive screening processes (Agyei, Tsopmo, \& Udenigwe, 2018). Nevertheless, bioinformatic prediction of especially active food peptides remains largely unexplored until now.

In the light of the above, this work aimed at, for the first time ever, investigating the emulsifying activity of potato peptides predicted by bioinformatics. We limited the initial 
search to patatin sequences, as this group of highly homologous proteins is the most abundant in potato juice (Bauw et al., 2006). Six peptide sequences, with potentially different conformation at the oil/water interface (i.e. $\alpha$-helix, $\beta$-strand or unordered), were identified by predicting their emulsifying activity (i.e. hydrophobic vector). Then, the emulsifying properties of synthetic peptides with the predicted sequences were determined in small scale assays. First, the interfacial properties of the peptides was assayed by drop tensiometry. Second, the physical and oxidative stabilities of fish oil-in-water emulsions were evaluated during storage. Last, the in vitro antioxidant activity of the peptides was tested.

\section{MATERIALS AND METHODS}

\subsection{Materials}

Synthetic peptides (purity $>70 \%$ by HPLC) were purchased from Chinapeptide Co., Ltd. (Shanghai, China). Commercial cod liver oil was kindly provided by Maritex A/S (Sortland, Norway), a subsidiary of TINE SA (Oslo, Norway) and stored at $-40{ }^{\circ} \mathrm{C}$ until use. The fatty acid composition (major fatty acids only) of the fish oil used was $\mathrm{C} 16: 0,9.5 \%$; $\mathrm{C} 16: 1,8.7 \%$; $\mathrm{C} 18: 1,16.3 \%$; $\mathrm{C} 20: 1,12.6 \%$; $\mathrm{C} 20: 5,9.2 \%$ and $\mathrm{C} 22: 6,11.4 \%$. The tocopherol content of the fish oil was: $\alpha$-tocopherol, $200 \pm 3 \mu \mathrm{g} / \mathrm{g}$ oil; $\beta$-tocopherol, $5 \pm 1 \mu \mathrm{g} / \mathrm{g}$ oil; $\gamma$-tocopherol, $96 \pm 3$ $\mu \mathrm{g} / \mathrm{g}$ oil and $\delta$-tocopherol, $47 \pm 1 \mu \mathrm{g} / \mathrm{g}$ oil. The peroxide value (PV) of the fish oil used was $0.38 \pm 0.04 \mathrm{meq} / \mathrm{kg}$ oil. The properties of the fish oil used were determined as described elsewhere (García-Moreno, Guadix, Guadix, Jacobsen, 2016). Sodium caseinate (Miprodan 30), which was used as positive control exhibiting excellent emulsifying activity, was provided by Arla Foods Ingredients amba (Viby J, Denmark). Protein content of sodium caseinate was reported as $92 \%(\mathrm{~N} \times 6.38)$. Native (non-denatured) potato protein $(85 \%$ protein, $\mathrm{N} \times 6.25$ ), isolated by a cold-extraction method from the potato juice was provided by KMC (Brande, Denmark). The native potato protein contained 21\% patatin (all isoforms) and 
$67 \%$ protease inhibitors (relative molar abundance) determined by LC-MS/MS (unpublished data). By colorimetric SDS-PAGE analysis (relative weight\%), the distribution was determined as $35 \%$ patatin (approximately $40 \mathrm{kDa}$ ) and $58 \%$ protease inhibitors $(10-25 \mathrm{kDa})$ (unpublished data). The discrepancy between relative molar abundance and relative weight $\%$ can be ascribed to differences in molecular weight and the non-specific nature of SDS-PAGE analysis. Potato protein was used as control to compare emulsifying and antioxidant activity of peptides and raw protein. All other chemicals and solvents used were of analytical grade.

\subsection{Bioinformatics}

Although protease inhibitors constitute a larger relative proportion of proteins in potato tubers, they are comprised of several sub-classes with high sequence variety. Patatins, however, are highly conserved on the sequence level with $84-96 \%$ sequence identity within the Kuras cultivar (Bauw et al., 2006). Consequently, we decided to limit our initial investigation to patatin sequences. From the UniProt Knowledgebase (The UniProt Consortium, 2017), we selected the first nine reviewed isoforms of patatin (out of 34) for analysis. The selected patatin isoforms are identified by the following accession numbers: P15478, P15477, Q3YJT5, P11768, Q2MY60, Q2MY43, Q42502, Q3YJS9, and Q3YJT3. We predicted the emulsifying potential of patatin peptides by calculating the hydrophobic vector of peptides up to a length of 30 amino acids, as function of its secondary structure (i.e. $\alpha$ helix, $\beta$-strand or unordered). The Kyte-Doolittle hydropathic scale was used as a common scale for the hydrophobicity of each amino acid (Kyte \& Doolittle, 1982).

\subsection{1 $\alpha$-helix peptides}

Alpha-helices have a periodicity of 3.6 amino-acid residues per turn, meaning that each residue corresponds to a $100^{\circ}$ or $5 / 9 \pi$ radians turn. Thus, hydrophobic residues placed alternately three or four residues apart will form a hydrophobic face in a helical peptide. 
123 Hydrophilic residues on the opposite face of the helix would result in the helix having a

124 hydrophilic face as well. A helical hydrophobic vector (A) can be calculated as follows (Eq.

125 1) (Eisenberg, Weiss, \& Terwilliger, 1982):

$$
A=\left|\sum_{n=1}^{w} K\left(a a_{n}\right) \cdot\left[\begin{array}{l}
\cos \left(n \cdot \frac{5}{9} \pi\right) \\
\sin \left(n \cdot \frac{5}{9} \pi\right)
\end{array}\right]\right|
$$

127 where $\mathrm{K}\left(\mathrm{aa}_{\mathrm{n}}\right)$ represents the Kyte-Doolittle hydropathic value, w is the peptide (sequence)

128 length, and $\mathrm{n}$ represents the number of a given amino acid in the peptide sequence.

129 A longer hydrophobic vector, perpendicular to the helical axis, directly correlates with higher 130 amphiphilicity of a peptide in helical conformation (Eisenberg et al., 1982). As increased 131 amphiphilicity in $\alpha$-helical peptides have been shown to increase emulsifying activity (Saito et 132 al., 1995 and Poon et al., 2001), the $\alpha$-score from our predictive model (i.e. vector length) 133 directly implies a potentially higher emulsifying activity of the peptide in a helical 134 conformation. According to (Eisenberg et al., 1982), this principle also applies to non-helical 135 peptide structures and can be generalized to amphiphilic peptides in any conformation.

136

137

138

140

$$
B=\left|\sum_{n=1}^{w} K\left(a a_{n}\right) \cdot\left[\begin{array}{l}
\cos (n \cdot \pi) \\
\sin (n \cdot \pi)
\end{array}\right]\right|
$$

143 where $\mathrm{K}\left(\mathrm{aa}_{\mathrm{n}}\right)$, w and $\mathrm{n}$ are defined as for Eq. 1.

\subsection{2 $\beta$-strand peptides}

Peptides with a $\beta$-strand secondary structure have side chains of the amino acids pointing alternatively above and below the plane of the $\beta$-strand (e.g. every $180^{\circ}$ or $\pi$ radians). This means that for a $\beta$-strand peptide to exhibit amphiphilicity, every second amino acid should be hydrophobic and every other should be hydrophilic (Dexter \& Middelberg, 2008). Thus, the hydrophobic vector for $\beta$-strand peptides (B) can be calculated as follows (Eq. 2): 
144 As described for the helical prediction model, a longer hydrophobic vector perpendicular to

145 the $\beta$-strand plane (i.e. higher $\beta$-score), is directly correlated with higher amphiphilicity and

146 thus a potentially higher emulsifying activity of the peptide in a $\beta$-strand conformation.

\section{$147 \quad$ 2.2.3 Half hydrophobic-half hydrophilic peptides ( $\gamma$-peptides)}

148 A third possibility for a peptide to display amphiphilic properties with emulsifying potential is

149 to have a hydrophobic and a hydrophilic half, allowing the peptide to orient perpendicularly

150 to the interface (Dexter \& Middelberg, 2008). These type of peptides could adopt $\alpha$-helix and

$151 \beta$-strand conformations or be unordered. The hydrophobic vector for $\gamma$-peptides $(\mathrm{G})$ was 152 calculated as follows (Eq. 3):

$$
G=\left|\sum_{n=1}^{\frac{1}{2} w} K\left(a a_{n}\right)-\sum_{n=\frac{1}{2} w+1}^{w} K\left(a a_{n}\right)\right|
$$

154 where $\mathrm{K}\left(\mathrm{aa}_{\mathrm{n}}\right)$, w and $\mathrm{n}$ are defined as for Eq. 1.

155 As for both $\alpha$-helical and $\beta$-strand peptides, the longer the hydrophobic vector, the higher the 156 amphiphilicity of the peptide implying potentially higher emulsifying activity. However, in 157 contrast to both $\alpha$-helical and $\beta$-strand peptides, the hydrophobic vector for each amino acid is 158 projected in the axial direction of the peptide, thereby making the hydrophobic vector axial 159 (head-to-tail) and not perpendicular to the peptide backbone.

\subsection{Interfacial tension - pendant drop method}

The dynamic interfacial tension of the peptides at the oil-water interface was determined using an automated drop tensiometer OCA20 (DataPhysics Instruments GmbH, Filderstadt,

163 Germany) at $25^{\circ} \mathrm{C}$. Peptides solutions $(0.1 \mathrm{wt} . \%)$ in $10 \mathrm{mM}$ sodium acetate $-10 \mathrm{mM}$

164 imidazole buffer ( $\mathrm{pH}$ 7) were prepared. The peptide solution (water phase) was filled into a syringe with a screwed needle. For each measurement, a small drop of the peptide solution was generated using the automated syringe into a quartz glass cuvette filled with fish oil (oil 
were transferred to the drop shape analysis software. Interfacial tension was calculated based on the shape analysis of a pendant drop according to the Young-Laplace equation (Eq. 4):

$$
\Delta \mathrm{P}=\gamma \cdot\left(\frac{1}{R_{1}}+\frac{1}{R_{2}}\right)
$$

where $\Delta \mathrm{P}\left(\mathrm{mN} / \mathrm{m}^{2}\right)$ is the pressure difference across the interface, $\gamma(\mathrm{mN} / \mathrm{m})$ is the interfacial tension and $\mathrm{R}_{1}$ and $\mathrm{R}_{2}(\mathrm{~m})$ are the principal radii of curvature of the pendant drop. Measurements were carried out in duplicate.

\subsection{Production of emulsions}

Peptides $(0.2$ wt. $\%)$ were dissolved in $10 \mathrm{mM}$ sodium acetate $-10 \mathrm{mM}$ imidazole buffer $(\mathrm{pH}$ 7). The peptide solutions were shaken $(100 \mathrm{rpm})$ overnight at room temperature to allow complete solubilization and rehydration of the peptides (when possible). Primary homogenization was done by adding the fish oil to the peptide-buffer solution and mixing at 18,000 rpm for 30 s by using a POLYTRON® PT1200E (Kinematic Inc., New York, USA). Secondary homogenization was done using a Microson XL2000 sonicator equipped with a P1 probe (Misonix, Inc., New York, USA). Emulsions were homogenized at an amplitude of $75 \%$ (maximum amplitude of $180 \mu \mathrm{m}$ ), running 2 passes of $30 \mathrm{~s}$ with a break of $1 \mathrm{~min}$ between passes. During sonication the emulsions were surrounded by iced water to minimize the increase in temperature. A total amount of $2 \mathrm{~g}$ of $5 \mathrm{wt} \%$ fish oil-in-water emulsion stabilized with $0.2 \mathrm{wt} . \%$ potato peptides was produced.

\subsection{Physical stability of the emulsions}

\subsubsection{Droplet size and creaming}

The droplet size distribution of the emulsions was measured immediately after production and after two days of storage at $50{ }^{\circ} \mathrm{C}$ by laser diffraction in a Mastersizer 2000 (Malvern Instruments, Ltd., Worcestershire, UK). Each emulsion was diluted in recirculating water (3000 rpm), until it reached an obscuration of $12 \%$. The refractive indices of sunflower oil 
(1.469) and water (1.330) were used as particle and dispersant, respectively. Results are given

193 in volume mean diameter $\left(\mathrm{D}_{4,3}\right)$. Measurements were made in triplicate. Due to the low

194 volume of emulsions produced, creaming was determined qualitatively by observing the

195 appearance of the emulsions.

\section{$196 \quad$ 2.5.2 Zeta potential}

197 The zeta potential of the emulsions was measured after one day of storage at room

198 temperature in a Zetasizer Nano ZS (Malvern instruments Ltd., Worcestershire, UK) with a

199 DTS1070 cell at $25^{\circ} \mathrm{C}$. Before analysis, the emulsions were diluted $(10 \mu \mathrm{L}$ emulsion in $5 \mathrm{~mL}$

200 buffer). The zeta potential range was set to -100 to $+50 \mathrm{mV}$ and the samples were analyzed

201 with 100 runs. Measurements were done in triplicate.

202

203

204

205

206

\subsection{Antioxidant activity of peptides and oxidative stability of the emulsions}

\subsubsection{In vitro antioxidant activity of peptides}

Peptides were dissolved in $10 \mathrm{mM}$ sodium acetate - $10 \mathrm{mM}$ imidazole buffer $(\mathrm{pH} 7)$ at 0.2 wt.\%. 1 1,1-Diphenyl-2-picrylhydrazyl (DPPH) radical scavenging activity, iron $\left(\mathrm{Fe}^{2+}\right)$ chelating activity and $\mathrm{Fe}^{3+}$ reducing power were measured as described elsewhere (GarcíaMoreno et al., 2016). The methods for antioxidant activity assays were modified slightly from the original to adapt for microplate readings using Eon ${ }^{\mathrm{TM}}$ microplate spectrophotometer (BioTek Instruments, Inc., Winooski, VT, USA).

\subsubsection{Electron spin resonance (ESR)}

The oxidative stability of the emulsions was first evaluated by ESR. ESR analysis was carried out using a benchtop MiniScope MS 5000 ESR spectrometer (MAGNETTECH GMBH, Germany). The instrument settings were as follows: magnetic field 320-360 mT, sweep time $60 \mathrm{~s}$, modulation $0.2 \mathrm{mT}$ and frequency $100 \mathrm{kHz}$. Emulsions were produced as described in section 2.4 and N-tert-Butyl- $\alpha$-phenylnitrone (PBN) (Sigma Aldrich, Søborg, Denmark) was 
added to the emulsions as an ethanol solution (concentration of $50 \mathrm{mg} / \mathrm{mL}$ ) to have $30 \mathrm{mM}$ of

217 PBN in the oil phase of the emulsion. The oxidative stability of the emulsions was determined

218 during $48 \mathrm{~h}$ storage at $50{ }^{\circ} \mathrm{C}$ and samples were measured at $0,6,12,24,36$ and $48 \mathrm{~h}$. For each

219 sampling point, emulsion samples $(50 \mu \mathrm{L})$ were transferred to borosilicate capillary tubes

220 before they were introduced to the cavity of the ESR. Analyses were performed in triplicate at

221 room temperature.

$222 \quad 2.6 .3$ Oxygraph system

223 An Oxygraph system (Hansatech Instrument Ltd., Norfolk, UK) was used to evaluate the

224 oxidative stability of the emulsions by continuously measuring the concentration of dissolved 225 oxygen in the emulsions. The Clark type polarographic oxygen sensor was calibrated daily 226 with air saturated and air depleted water at $30^{\circ} \mathrm{C}$ and adjusted for atmospheric air pressure.

227 Emulsions $(1 \mathrm{~mL})$ were placed in a stirred, water-jacketed cell at $30{ }^{\circ} \mathrm{C}$ and a background 228 oxygen uptake rate $\left(\mathrm{R}_{\mathrm{B}}\right)$ was recorded for 5-10 min. Then, $\mathrm{Fe}^{2+}$ was added as a prooxidant 229 through a capillary opening in the cell. $5 \mu \mathrm{L}$ of a daily prepared $2.5 \mathrm{mg} / \mathrm{mL} \mathrm{Fe}^{2+}$ solution in 230 distilled water was injected to a final $\mathrm{Fe}^{2+}$ concentration of $45 \mu \mathrm{M}$. After the injection of $\mathrm{Fe}^{2+}$, 231 a drop in oxygen concentration $\left(\Delta \mathrm{O}_{2}\right)$ was recorded followed by a constant oxygen uptake 232 rate $\left(\mathrm{R}_{\mathrm{T}}\right)$. A net oxygen uptake rate $\left(\mathrm{R}_{\mathrm{N}}\right)$ was calculated as $\mathrm{R}_{\mathrm{T}}$ minus $\mathrm{R}_{\mathrm{B}}$. Both $\mathrm{R}_{\mathrm{N}}$ and $\Delta \mathrm{O}_{2}$ 233 were employed to evaluate the oxidative stability of the emulsions. Measurements were 234 carried out in duplicate.

\subsection{Statistical analysis}

236 Statgraphics 18 (Statistical Graphics Corp., Rockville, MD, USA) was used for data analysis.

237 Data were expressed as mean \pm standard deviation. Firstly, multiple sample comparison 238 analysis was performed to identify significant differences between samples. Secondly, mean 
values were compared by using the Tukey's test. Differences between means were considered

$240 \quad$ significant at $\mathrm{p}<0.05$.

\section{$241 \quad 2.8$ Protein modelling and peptide visualization}

242 In order to determine localization of the predicted peptides within their mature form protein of 243 origin, we modelled the protein structure of Patatin-B2 (UniProt AC\# P15477) for $\alpha 1, \alpha 2$, and $244 \alpha 3$ (QMEAN -0,75); Patatin-05 (UniProt AC\# Q3YJT5) for $\beta 1$ (QMEAN -0,95); Patatin 245 Group M-1 (UniProt AC\# P11768) for $\gamma 1$ (QMEAN -0,73); and Probable inactive patatin-3246 Kuras 1 (UniProt AC\# Q3YJS9) for $\gamma 2$ (QMEAN -1,34). All models were built with The 247 SwissModel Workspace (Waterhouse et al. 2018) using the X-ray crystal structure of 248 monomeric Patatin-17 (Wijeyesakere, Richardson, \& Stuckey, 2016) as structural template 249 (SMTL ID 4pka.1.A). Subsequently, models were visualized in The PyMOL Molecular 250 Graphics System, Version 1.5.0 (Schrödinger, LLC.). For visualization of individual peptides 251 with visible side chains, residues were colored according to the SwissModel hydrophobicity 252 scale (Very hydrophilic residues in blue (R, K, D, E, N, Q, H), partially hydrophilic in purple 253 (P, Y, W, S, T, G), partially hydrophobic in pink (A, M, C, F), and very hydrophobic in red $254(\mathrm{~L}, \mathrm{~V}, \mathrm{I}))$.

255 Helical wheel projections were modelled using the HELIQUEST web server (Gautier, 256 Douguet, Antonny, \& Drin, 2008). For each model, the mean hydrophobicity $<\mathrm{H}>$ is 257 calculated using residue-specific hydrophobicity scores (Fauchere, \& Pliska, 1983). 258 Furthermore, the mean amphipathic moment $\langle\mu \mathrm{H}\rangle$ perpendicular to the backbone axis is 259 calculated (Eisenberg et al., 1982). Both calculated physico-chemical properties are 260 normalized to the length of the peptide. 


\section{RESULTS AND DISCUSSION}

262

\subsection{Prediction of emulsifying potato peptides by bioinformatics}

Patatins have been reported to be the most abundant of highly conserved protein families in potatoes and to exhibit superior emulsifying activity when compared to protease inhibitors. These findings were mainly attributed to differences in hydrophobicity between these protein fractions (Schmidt et al., 2018; Bauw et al. 2006). Therefore, nine patatin sequences from Solanum tuberosum were extracted from the UniProt knowledgebase (Bateman et al., 2017) and used for prediction of embedded peptides with emulsifying activity.

Emulsifying peptides, which could adopt different secondary structure, present hydrophobic and hydrophilic parts in their molecule. Peptides with $\alpha$-helix and $\beta$-strand secondary structures exhibit facial amphiphilicity (e.g. having hydrophilic and hydrophobic faces in their molecule), which allows them to orientate parallel to the interface. On the other hand, $\gamma$ peptides with hydrophobic and hydrophilic halves could orientate perpendicularly to the interface (Dexter \& Middelberg, 2008). Interestingly, patatins are highly structured proteins at room temperature with $33 \%$ of the residues adopting $\alpha$-helical and $46 \% \beta$-stranded structures (Pots, De Jongh, Gruppen, Hamer, \& Voragen, 1998). Thus, emulsifying peptides with different secondary structures, and thus potentially different conformation at the oil/water interface, may be embedded within patatin sequences.

Three regions in the patatin sequences showed predicted emulsifying potential for embedded peptides in $\alpha$-helical conformation, one region showed predicted emulsifying potential for an embedded peptide in $\beta$-strand conformation, and two regions had the potential to give half hydrophobic and hydrophilic emulsifying peptides. From each region, the peptide with the highest predicted amphiphilicity was selected for synthesis (Table 1). Three peptides with 
potential $\alpha$-helix ( $\alpha 1, \alpha 2$ and $\alpha 3)$ conformation, one with potential $\beta$-strand $(\beta 1)$ structure, and two potentially half hydrophobic and half hydrophilic peptides $(\gamma 1$ and $\gamma 2)$ were investigated. To investigate the native conformation of the predicted emulsifier peptides, we modelled the structure of the patatin isoform from which the peptides originate (Fig. 1, top). Using a hydrophobic coloring scheme, we also visualized the distribution of amino acids in the peptides (Fig. 1, bottom). This facilitated identification of potential inherent amphiphilicity of the peptides in their native conformation as well as the potential of adopting the predicted emulsifying conformation. Interestingly, all peptides (with the exception of $\alpha 2$, which appear to have a quite amphiphilic antiparallel $\beta$-strand conformation), are located in regions of the proteins with predominant $\alpha$-helical and/or unordered conformation. Especially $\gamma 1$ has a high degree of helical content, as it, in the native conformation, forms a partially buried $\alpha$-helix, where the $\mathrm{N}$-terminal end (predominantly hydrophobic) is located near the core of the protein, while the C-terminal end (predominantly hydrophilic) is located in a solvent exposed loop region. Furthermore, the central part of $\gamma 1$ appears to be quite amphiphilic by presenting a hydrophobic (red) phase. Although the helical segment of $\alpha 3$ and $\gamma 2$ are significantly shorter, they also appear to be amphiphilic with a well-defined hydrophobic phase. The content of each peptide located in either $\alpha$-helical or $\beta$-strand regions in the native conformation, are summarized in Table 1.

As most of the predicted peptides are found in (partially) helical regions within the native proteins, we decided to visualize the amphiphilic potential using helical wheel projections. In silico, we forced the full-length peptide into a helical conformation (Fig. 1S, top). This merely depicts the peptides in an $\alpha$-helix by projecting helical constraints onto the peptide sequence and does not necessarily correlate with the in vitro conformation at the interface. Based on the full-length projections, we selected the segment of each peptide that produced the largest undisrupted hydrophobic phase and/or largest mean hydrophobic moment (Fig. 1S, bottom). 
The calculated mean hydrophobicity $\langle\mathrm{H}\rangle$ and mean hydrophobic moment $\langle\mu \mathrm{H}\rangle$ of both fulllength and segmented projections are summarized in Table S1. For the full length peptides, $\langle\mu \mathrm{H}\rangle$ is higher for the $\alpha$-peptides, which is expected based on the parameters used in the prediction model, where similar assumptions are made. Alpha-3 produces the, by far, most amphiphilic helix (highest $\langle\mu \mathrm{H}\rangle$ of all full-length peptides). When considering only the

314 selected segments of each peptide, $\langle\mu \mathrm{H}\rangle$ of $\alpha 3$ increased even further (38\% increase relative 315 to full-length $\alpha 3)$. Interestingly, $\langle\mu \mathrm{H}\rangle$ for the selected segments of both $\gamma$-peptides significantly increased ( $199 \%$ for $\gamma 1$ and $326 \%$ for $\gamma 2$ ) to a level comparable to $\langle\mu \mathrm{H}\rangle$ of the $\alpha 3$ segment.

It is noteworthy that, since the algorithm employed did not normalize the hydrophobic vector according to the peptide length, the predicted emulsifying peptides were between 27 and 29 amino acids long (apart from $\alpha 3$ ). This was close to the maximum length allowed by the algorithm. The maximum length of 30 amino acid residues was selected because peptides shorter than this diffuse faster and thereby facilitate initial adsorption at the oil/water interface. Moreover, these peptides have increased rate of conformation change at the oil/water interface since they are too small to possess tertiary structure (Enser, Bloomberg, Brock, \& Clark, 1990). In addition, our prediction is aligned with the study of Enser et al. (1990) indicating that the emulsifying activity increased considerably for $\alpha$-peptides between 22 and 29 residues when compared to peptides having 8-18 residues. The authors attributed this fact to an increase in $\alpha$-helicity of the peptides in aqueous solution when going from 11 to 22 amino acid residues, which correlated well with the higher potential of larger peptides to 330 adopt a larger proportion of well-defined secondary structure due to the flexible nature of 331 peptide termini.

332 The highest score (e.g. highest predicted amphiphilicity) was found for $\gamma$-peptides ( $\gamma 1$ and $\gamma 2)$ followed by $\beta 1, \alpha 2, \alpha 1$, and $\alpha 3$ (Table 1). These results indicated that the $\gamma$-peptides selected 
334 had more pure hydrophobic and hydrophilic regions when compared to the

335 hydrophilic/hydrophobic faces of $\alpha$ - and $\beta$-peptides. The lowest score of $\alpha 3$ obtained by the 336 algorithm, which did not correlate with its mean hydrophobic moment (Table S1), is 337 explained by the lack of normalization for peptide length in the algorithm, as $\alpha 3$ is the shortest 338 of the predicted peptides. Alpha-3 was, however, also selected based on its high content of 339 lysine, which resulted in high $\mathrm{pI}$ (e.g. positive net charge at $\mathrm{pH}$ 7). On the contrary, the rest of 340 the peptides had a $\mathrm{pI}$ lower than 7 , which resulted in a negative net charge at $\mathrm{pH} 7$ (Table 1).

341 In emulsions, the charge of the o/w interface may greatly affect oxidative stability, especially

342 when prooxidants such as metal ions are present (Berton-Carabin, Ropers, \& Genot, 2014).

343 It is also worth mentioning that the peptides tested do not have any free cysteine, which could

344 be a source of inter-peptide covalent bond formation. That means that any potential self345 assembly of peptides in the aqueous phase would be driven by weaker forces (i.e. ionic 346 interactions between charges and hydrophobic interactions) and consequently easily disrupted 347 during homogenization.

\subsection{Interfacial tension}

349 Emulsifying peptides have the ability to rapidly adsorb and re-orientate at the interface in 350 order to reduce interfacial tension (García-Moreno et al., 2016). Thus, the evolution of the 351 interfacial tension between fish oil and peptide solutions with time was evaluated (Fig. 2). It was observed that the interfacial tension between fish oil and distilled water was practically constant over time, indicating a minimum influence of the naturally present surface active impurities in the fish oil (e.g. mono- and di-glycerides). However, interfacial tension between fish oil and all peptide solutions showed an initial decrease when compared to oil-water;

356 leveling off at short time ( $<5 \mathrm{~min}$ ) for $\alpha 3$, casein and $\gamma 1$ and after $15 \mathrm{~min}$ for $\alpha 1, \alpha 2, \beta 1$ and 357 potato protein (Fig. 2). 
Higher initial and equilibrium values were found for $\alpha 1, \alpha 2, \beta 1$ and $\gamma 2$ when compared to $\alpha 3$, casein and $\gamma 1$ (Fig. 2). Alpha-1 and $\alpha 2$ peptide solutions were cloudy, indicating that the peptides were not totally soluble in the buffer used and this may explain their higher interfacial tension results (See Fig. $2 S$ in the Supplementary Material). Moreover, $\alpha 3$, that was totally soluble, presented a short length resulting in faster diffusion to the interface, which could explain its lower initial interfacial tension when compared to $\alpha 1$ and $\alpha 2$. Previous studies also pointed out an inverse relation between protein size and adsorption rate, especially in drop tensiometry where adsorption is mainly controlled by diffusion (Jung, Gunes and Mezzenga, 2010; Schröder, Berton-Carabin, Venema, \& Cornacchia, 2017).

367 On the other hand, $\beta 1$ and $\gamma 2$, having similar solubility and size as $\gamma 1$, presented higher initial and equilibrium interfacial tension values when compared to $\gamma 1$ (Fig 1). This may be attributed to the better defined hydrophobic and hydrophilic regions in $\gamma 1$, as indicated by its 370 highest score (Table 1). The effect of peptide amphiphilicity (e.g. the existence of 371 hydrophobic patches that allow the peptides to anchor at the interface), rather than their size, 372 on decreasing interfacial tension, has also been highlighted in literature (Schröder et al., 373 2017). This also correlates well with the observations for $\alpha 3$ (in comparison to $\alpha 1$ and $\alpha 2$ ), as 374 the mean helical hydrophobic moment is significantly larger (Table S1), indicating an effect 375 of both size and amphiphilicity. It is also worth noting that $\gamma 1$ resulted in both lowest initial 376 interfacial tension and the lowest equilibrium value of interfacial tension (even when 377 compared to casein, which is an excellent protein emulsifier for oil-in-water emulsions). 378 These results indicate that $\gamma 1$ could be capable of adsorbing faster to the oil-water interface 379 and thereby decrease interfacial tension more rapidly, accounting for an increased rate of 380 droplet breakup, in comparison to the rest of peptides and proteins assayed.

381 In the case of potato protein, although it presented high initial interfacial tension, it decreased 382 over time resulting in an equilibrium value similar to casein (Fig. 2). This indicated that 
383 potato protein requires longer time to adsorb and rearrange at the interface in order to

384 decrease interfacial tension when compared to casein and $\gamma 1$. As the potato protein is a 385 complex mixture of native proteins spanning a wide range of molecular weights, sizes, and

386 structures, other factors may contribute to the observed result. Smaller proteins and peptides 387 that adsorb poorly but diffuse faster to the interface may be responsible for the high initial 388 surface tension. Over time, larger proteins diffuse to and rearrange at the interface thereby 389 producing strong adsorption that outcompete the smaller proteins and peptides ultimately resulting in a low equilibrium surface tension.

\subsection{Physical stability of emulsions}

392 Emulsifying peptides adsorb at the interface and stabilize oil-in-water emulsions by providing 393 steric hindrances and electrostatic repulsions (Cheng, Chen, \& Xiong, 2014). Table 2 shows

394 the $\mathrm{pH}$ of the emulsions, which ranged from 5.7 to 6.9 . At this $\mathrm{pH}$, which was above the pI of 395 the peptides and proteins assayed (apart from $\alpha 3$ ), the peptides as well as casein and potato 396 protein were negatively charged and led to negative zeta potentials in the emulsions (Table 2).

397 Most of the emulsions, except from $\alpha 3$ and potato protein-stabilized emulsions, showed 398 highly negative surface charges $(<-30 \mathrm{mV})$, which are expected to enhance physical stability 399 by providing strong electrostatic repulsions (e.g. overcoming van der Waals and hydrophobic 400 interactions) (Ghelichi, Sørensen, García-Moreno, \& Jacobsen, 2017). Differences in zeta 401 potential are mainly attributed to net charge of peptides (e.g. presence of $\mathrm{R}, \mathrm{K}, \mathrm{D}$ and $\mathrm{E}$ residues), which explained the significantly higher negative zeta potential values of $\gamma 1, \gamma 2$ and $\beta 1$ when compared to $\alpha 1$ and $\alpha 3$ (Tables 1,2 ). Furthermore, surface charge is also affected by 404 other factors like amount of peptides/protein adsorbed at the interface (García-Moreno et al., 2016). For instance, although $\alpha 1$ and $\alpha 2$ showed similar net charge, a significantly higher negative zeta potential was found for emulsions stabilized with $\alpha 2$ when compared to $\alpha 1$. This 
might be explained by a lower amount of $\alpha 1$ adsorbed at the interface, since $\alpha 1$ emulsion had

408 larger droplets when compared to $\alpha 2$ emulsion (Table 2). It indicated, for the same total 409 amount of emulsifier and oil volume fraction, less droplets and smaller interfacial area in $\alpha 1$ 410 stabilized emulsion.

411 As expected from the interfacial tension results (Fig. 2), significant differences were observed 412 in droplet size (Table 2) and droplet size distributions (see Fig. 3S in Supplementary Material) 413 between the different emulsions. Gamma-1, casein and $\alpha 3$ presented higher emulsifying 414 activity which led to emulsions with significantly smaller droplet size after production when 415 compared to the other (Table 2). Nevertheless, it was observed that emulsion stabilized with $416 \alpha 3$ totally separated after storage, which could be attributed to its low net zeta potential. This 417 could also be ascribed to the structure of $\alpha 3$ at the interface. The large mean hydrophobic 418 moment may be responsible for a strong initial interaction, which is in agreement with the low 419 interfacial tension. However, a quite small hydrophobic phase and the overall low content of 420 very hydrophobic amino acids (21\%) could be responsible for the helix not docking strongly 421 at the interface and being more susceptible to external forces over time. In contrast, emulsions stabilized with casein significantly increased its droplet size due to flocculation and/or coalescence resulting in middle-high creaming. Previous studies highlighted that coalescence

424 in emulsions prepared using ultrasonic equipment was mainly due to the low adsorption rate 425 of emulsifier (e.g. due to the low concentration employed) and the increased likelihood of 426 droplets collision (e.g. due to the high energy density in ultrasonic homogenization) 427 (O'Sullivan, Murray, Flynn, \& Norton, 2015). On the contrary, emulsion stabilized with $\gamma 1$ 428 neither increased its droplet size during storage nor had visible creaming (Table 2). This 429 denoted that sufficient peptide was adsorbed at the interface to avoid coalescence and that the 430 initial droplet size was low enough to prevent emulsion physical destabilization (e.g. 431 creaming) (McClements, 2005). 
432 Despite the similar interfacial tension results found for $\alpha 1, \alpha 2, \beta 1$ and $\gamma 2$ (Fig. 2), the droplet

433 size of these emulsions was significantly different (Table 2). Emulsion stabilized with $\alpha 2$ had

434 the smallest droplet size after production followed by $\beta 1$, and then $\alpha 1$ and $\gamma 2$. The enhanced

435 emulsifying activity of $\alpha 2$ when compared to $\alpha 1$ could be attributed, apart from the better 436 solubility of $\alpha 2$ (e.g. less cloudy solution, see Fig. $2 \mathrm{~S}$ in Supplementary Material), to the fact 437 that three $\mathrm{P}$ residues were present in the sequence of $\alpha 1$. P residues (as well as $\mathrm{G}$ residues) are 438 known to have a very low propensity for $\alpha$-helicity and are usually found in either disordered 439 or turn regions in native proteins (Costantini, Colonna, \& Facchiano, 2006). Consequently, 440 high content of either $\mathrm{P}$ or $\mathrm{G}$ reduces the probability of $\alpha$-helicity in a peptide, while an 441 increase in $\alpha$-helicity has been reported to increase emulsifying activity of peptides (Enser et 442 al., 1990). As both $\alpha 1$ and $\alpha 2$ contain several $\mathrm{G}$ residues distributed quite evenly throughout 443 the peptide, this may decrease the stability of potential helices formed. If located in a helix, $\mathrm{P}$ 444 will, due to the backbone constraints originating from the pyrrolidine side chain, produce a 445 kink in the helix of approximately $26^{\circ}$ (Barlow, \& Thornton, 1987). If the direction of the 446 kink is unfavorable relative to the curvature of the oil droplet, inclusion of one or more $\mathrm{P}$ will 447 weaken the interaction of the helix with the oil thereby decreasing emulsifying potential 448 and/or stability. On the contrary, if the kink is favorable to the curvature of the oil droplet, the 449 inclusion of $\mathrm{P}$ will favor the adsorption of the helix at the interface. This may be the case for $450 \gamma 1$, although further research is needed.

451 It is worth noting that the emulsions stabilized with $\alpha 1, \alpha 2, \beta 1$ and $\gamma 2$ had droplet sizes higher 452 than $4.5 \mu \mathrm{m}$ after storage, resulting in creaming for all these emulsions. It should be also 453 noted that the emulsion stabilized with raw potato protein showed considerably larger droplet 454 size when compared to emulsions stabilized with peptides and casein, leading to phase 455 separation during storage (Table 2). This is in agreement with previous findings indicating 
rapid creaming of oil-in-water emulsions stabilized with only potato protein (Cheng, Xiong,

\& Chen, 2010). Nevertheless, and as indicated by the interfacial tension measurements (Fig.

2), the performance of the potato protein used may improve when using homogenization methods that slowly disrupt oil droplets (e.g. mixing devices such as Stephan mixer). It will provide longer time for potato protein to diffuse and adsorb at the interface in order to stabilize the newly created droplets. This remains to be investigated.

462 Altogether, the results revealed superior emulsifying activity of the $\gamma 1$ peptide. This correlated well with the highest score predicted for this peptide (Table 1) as wells as the lowest initial and equilibrium values of interfacial tension obtained for $\gamma 1$, when compared to the rest of peptides and proteins tested (Fig. 2). $\gamma$-peptides with the appropriate axial amphiphilicity have the potential to possibly orientate perpendicularly at the oil/water interface and stabilize oilin-water emulsions. This may lead to higher packing density at the interface when compared to highly facial amphiphilic peptides ( $\alpha$-helix and $\beta$-strand peptides) (Dexter \& Middelberg, 2008), which could result in enhanced interfacial structure, although likely demanding a higher amount of peptide to cover the interface due to the direction. However, the localization of $\gamma 1$ in Patatin Group M-1 (Fig. 1) and the potential for producing a (partial) amphiphilic $\alpha$ helix at the interface, indicates that perpendicular packing at the interface may not be the mechanism of emulsifying action for $\gamma 1$. In fact, the high emulsifying activity may be a sum of several factors. Besides amphiphilic interaction with the oil droplet, the P residue may be 475 placed in a position, where it induces a kink in the helix that makes it bend in accordance with 476 the droplet curvature, thereby increasing the strength of the interaction. The relatively large 477 hydrophobic phase of the amphiphilic helix (assuming only partial helical conformation as 478 outlined for the $\gamma 1_{6-15}$ segment seen in Fig. S1) may be responsible for a strong and durable 479 interaction with the oil droplet. Furthermore, the free and predominantly hydrophilic and 480 highly charged C-terminal of the peptide could be fully solvent exposed thereby producing 
steric hindrance and electrostatic repulsion forces, which in turn increases the stability of the emulsion over time. In any case, this needs to be confirmed by studying the in situ structure of the peptides at the oil/water interface, which is currently under investigation in our lab.

\subsection{Antioxidant activity of peptides and oxidative stability of emulsions}

Emulsifying potato peptides, which could also have antioxidant activity, are of special interest. They may retard lipid oxidation in oil-in-water emulsions by exhibiting their antioxidant properties at the oil/water interface (i.e. place where autoxidation is initiated due to the contact between prooxidants and lipids) (García-Moreno et al., 2016). Thus, in vitro antioxidant activity of the predicted peptides, as well as oxidative stability of the emulsions stabilized with these peptides, has been investigated in this study.

\subsubsection{In vitro antioxidant activity of peptides}

Patatin, as well as potato peptides, have been reported to exhibit antioxidant activity due to their ability to scavenge free radicals, donate electrons and/or chelate metal ions (Kudo, Onodera, Takeda, Benkeblia, \& Shiomi, 2009; Wang \& Xiong, 2005; Liu et al., 2003). Fig. 3a shows the ability of the predicted emulsifier peptides, casein and non-hydrolyzed potato protein to scavenge DPPH radical. It was observed that $\beta 1$, followed by $\alpha 1$, showed significantly higher radical scavenging activity when compared to the other peptides. Beta-1

498 and $\alpha 1$ present one $\mathrm{M}$ residue in their sequence, which is a highly oxidizable amino acid due to its nucleophilic sulfur-containing side chain (Elias, Kellerby, \& Decker, 2008). Moreover,

$500 \quad \beta 1$ contains up to $4 \mathrm{~T}$ residues, three of them in consecutive order, which could enhance 501 radical inhibition by donation of hydrogen from its hydroxyl group. On the other hand, $\alpha 1$ is 502 the richest peptide in aromatic residues such as $\mathrm{F}$ and $\mathrm{Y}$, which have strong radical 503 scavenging ability through direct transfer of electrons (Nwachukwu \& Aluko 2019). These 504 findings are in agreement with previous studies reporting short potato peptides $(<1 \mathrm{kDa})$ with 
radical scavenging activity, possibly due to the presence of $\mathrm{M}, \mathrm{T}, \mathrm{Y}$ and $\mathrm{F}$ residues (Cheng,

506 Chen, \& Xiong, 2010; Kudo et al., 2009). It is noteworthy that the potato protein studied showed significantly higher DPPH scavenging activity $(79.6 \pm 3.6 \%$ at $2 \mathrm{mg} / \mathrm{mL})$ compared to and $\mathrm{W}$ residues in unprocessed potato protein (especially in proteases inhibitors), which exhibit strong antioxidant activity (Cheng, Xiong \& Chen, 2010). Higher DPPH scavenging activity for patatin was reported by Liu et. $(2003)\left(\mathrm{IC}_{50}=0.582 \mathrm{mg} / \mathrm{mL}\right)$ when compared to the potato protein studied in this work, whereas lower radical inhibition was found for patatin containing different isoforms $\left(\mathrm{IC}_{50}=25.63 \mathrm{mg} / \mathrm{mL}\right.$ ) (Sun et al., 2013). This may be ascribed to

514 the complexity of the crude potato protein compared to purified patatin.

A considerably low metal $\left(\mathrm{Fe}^{2+}\right)$ chelating activity was observed for all the peptides, especially when compared to casein, which is known as a good metal chelator (Fig. 3b). Indeed, this correlated well with previous results showing low or no metal chelating activity for potato peptides between $2-4 \mathrm{kDa}$ at concentrations lower than $5 \mathrm{mg} / \mathrm{mL}$ (Cheng, Chen, \& Xiong, 2010). Nevertheless, short potato peptides ( $<1 \mathrm{kDa})$, which have higher negative charge (carboxyl groups)-to mass ratios than large peptides, have been reported to bind metal ions more efficiently (Cheng, Chen, \& Xiong, 2010). This is a general trend also found for peptides from other protein sources (e.g. fish or milk), where low molecular weight peptides ( $<1 \mathrm{kDa}$ ) exhibit significantly higher metal chelating activity than large peptides (GarcíaMoreno et al., 2016; O'Loughlin et al., 2014). In any case, it should be highlighted that, besides the lower content of $\mathrm{H}$ residues (e.g. which exhibit chelating activity through its imidazole ring) for $\gamma 2$ when compared to $\alpha 1$ and $\alpha 2$ peptides, $\gamma 2$ exhibited significantly higher metal chelating activity when compared to the rest of peptides studied ( $\sim 3 \mathrm{kDa}$ ) (Fig. 3b). This could be attributed to $\gamma 2$ having a higher content of acidic residues with carboxyl groups in the side chain (Nwachukwu \& Aluko 2019). Finally, it should be mentioned that the 
peptides showed a significantly lower $\left(\mathrm{Fe}^{3+}\right)$ reducing power at the concentration assayed (2 $531 \mathrm{mg} / \mathrm{mL}$ ), when compared to casein and potato protein (Fig. 3c). Although there are not relevant data for potato protein in the literature, these low values are not surprising, since, for example, up to $15-30 \mathrm{mg}$ of fish protein hydrolysate per milliliter were required to reach absorbance values above 0.5 at $700 \mathrm{~nm}$ (García-Moreno et al., 2016; García-Moreno et al., 2014).

\subsubsection{Oxidative stability of emulsions}

First, oxidative stability of emulsions was investigated by using ESR spin trapping, where oxidation was accelerated by heating. PBN, which reacts with lipid radicals (e.g. peroxyl and alcoxyl radicals) yielding more stable radicals (spin adducts), was used as spin trap (Zhou \& Elias, 2012). The ESR spectra of PBN-adducts formed in fish oil-in-water emulsions consisted of three broad lines (Fig. 4a), showing the common coupling for nitroxyl radicals. This correlated well with the ESR spectra of PBN-adducts formed in bulk fish oil (Velasco, Andersen, Skibsted, 2005), and indicates that the radicals trapped by PBN were produced in the oil phase of the emulsions. Hence, higher formation of PBN-spin adducts (e.g. measured as the peak-to-peak amplitude of the middle-field line of the ESR spectra), denoted higher lipid oxidation (Andersen \& Skibsted, 2008).

Fig. 4b shows the generation of PBN-lipid adducts during storage of fish oil-in-water emulsions at $50{ }^{\circ} \mathrm{C}$. It was found that the emulsion stabilized with $\alpha 1$ was significantly more oxidized after $48 \mathrm{~h}$ storage when compared to emulsions stabilized with $\alpha 2$ and casein (which did not show significant differences between them at $48 \mathrm{~h}, \mathrm{p}>0.05$ ). Casein exhibited significantly higher chelating activity and reducing power when compared to $\alpha 1$, which could explain the higher oxidative stability of the emulsion stabilized with casein. Nonetheless, this is not the case for $\alpha 2$, which showed significantly lower radical scavenging and reducing power than $\alpha 1$ (Fig. 3). Therefore, the higher oxidative stability of $\alpha 2$-stabilized emulsion, 
when compared to $\alpha 1$, should be attributed to other properties such as higher adsorption at the interface (as indicated by its higher negative zeta potential but a similar net charge, Table 2). Higher peptide adsorption may lead to more densely packed interfaces, resulting in enhanced interfacial layer by decreasing the accessibility of prooxidants to lipids (García-Moreno et al., 2016). Surprisingly, emulsions stabilized with $\beta 1, \gamma 1, \gamma 2$ and potato protein showed a decrease in the peak-to-peak amplitude after 6-24 h (see Fig. 4S in Supplementary Material for specific details for $\gamma 1$-stabilized emulsion). This led to significantly lower intensity after $48 \mathrm{~h}$ storage at $50{ }^{\circ} \mathrm{C}$ for these emulsions when compared to emulsions stabilized with $\alpha 1, \alpha 2$ and casein (Fig. 4a). Previous ESR studies on fish oils also reported very low steady state concentrations of PBN spin adducts due to a fast decay of PBN spin adducts as a consequence of the reaction with new radicals to form diamagnetic species (Falch, Velasco, Aursand, \& Andersen, 2005; Velasco et al., 2005). Interestingly, emulsions stabilized with $\beta 1, \gamma 1, \gamma 2$ and potato protein showed brown colour during storage at $50{ }^{\circ} \mathrm{C}$, which was not observed for emulsions stabilized with $\alpha 1, \alpha 2$ and casein (see Fig. 5S in Supplementary Material). This may indicate peptide/protein co-oxidation including non-enzymatic browning reactions ( $\mathrm{Lu}$,

570 Nielsen, Baron, Diehl, \& Jacobsen, 2013), which could be related to advanced stages of 571 oxidation.

572 Secondly, oxidative stability of emulsions was determined by using the Oxygraph method, where oxidation is accelerated by the addition of $\mathrm{Fe}^{2+}$. Fig. 5a shows the drop in oxygen 574 concentration $\left(\Delta \mathrm{O}_{2}\right)$ in the emulsions after adding $\mathrm{Fe}^{2+}$. Mozuraityte, Rustad, and Storr $\varnothing$ (2008) attributed this initial drop in dissolved oxygen to the oxidation of $\mathrm{Fe}^{2+}$ to $\mathrm{Fe}^{3+}$ by pre576 existing lipid hydroperoxides. This results in alkoxyl radicals, which further react with fatty 577 acids leading to lipid radicals and formation of lipid peroxides by oxygen consumption. After 578 equilibrium between $\mathrm{Fe}^{2+}$ and $\mathrm{Fe}^{3+}$ is reached, a linear oxygen uptake takes place due to the 
579 lower pro-oxidant effect caused by $\mathrm{Fe}^{3+}$ (Mozuraityte, Kristinova, Rustad, \& Storrø, 2016).

580 Hence, higher $\Delta \mathrm{O}_{2}$ values as well as more negative net oxygen uptake rate $\left(\mathrm{R}_{\mathrm{N}}\right)($ Fig. $5 \mathrm{~b})$

581 indicate lower oxidative stability of emulsions.

582 It was observed that $\mathrm{R}_{\mathrm{N}}$ was not significantly different for the emulsion stabilized with casein

583 when compared to the values obtained for emulsions stabilized with either $\alpha 1, \beta 1, \gamma 1$ or $\gamma 2$.

584 However, significantly more negative $R_{N}$ values were found for $\alpha 3$, when compared to the

585 rest of the emulsions (Fig. 5b). Hence, the lower oxidative stability of $\alpha 3$ could be attributed

586 to the low physical stability of this emulsion, even soon after preparation, which indicates

587 more accessibility of prooxidants to the oil. Similarly, no significant differences were

588 observed in the $\Delta \mathrm{O}_{2}$ value for emulsion stabilized with casein $(\sim 40 \mu \mathrm{M})$ when compared to

589 emulsions stabilized with $\beta 1, \gamma 1$ and $\gamma 2$ (Fig. 5a). This indicates that these emulsions were

590 significantly more oxidatively stable when compared to emulsions stabilized with $\alpha 1$ and $\alpha 2$

$591(\sim 50 \mu \mathrm{M})($ Fig. 5). It can be attributed to: i) higher chelating activity of casein and $\gamma 2$, ii)

592 higher radical scavenging activity showed by $\beta 1$, and iii) higher physical stability of $\gamma 1$. It is

593 noteworthy that Oxygraph results (Fig. 5), where oxidation was measured right after

594 production of the emulsions (still physically stable emulsions), correlated reasonably well

595 with ESR results for $\alpha 1$ and $\alpha 2$, but not for the rest of the emulsions. This may be explained

596 by the different conditions to accelerate oxidation employed (temperature vs. iron addition) as

597 well as the different time scale of the analyses. For instance, no change in color was observed 598 for the emulsions stabilized with $\beta 1, \gamma 1$ and $\gamma 2$ during the short time scale of the Oxygraph 599 analysis. This indicates the absence of advanced lipid oxidation products formed through non600 enzymatic browning (e.g. carbonyl-amine adducts). 
601

602

603

604

605

606

607

608

609

610

611

612

613

614

615

616

617

618

619

620

621

622

623

624

\section{CONCLUSIONS}

Bionformatics allowed the prediction of peptides with emulsifying activity derived from patatin. The predicted peptides have a potentially different conformation at the interface $(\alpha-$ helix, $\beta$-strand or unordered). Lower physical and oxidative stabilities were observed for emulsions stabilized with $\alpha 1, \alpha 2$ and $\alpha 3$ peptides, which were predicted to have a low amphiphilic score. Nevertheless, the peptide predicted to have the highest amphiphilic score (a peptide with hydrophobic and hydrophilic halves, $\gamma 1$ ) showed the highest emulsifying activity. Structural modelling indicated that the mechanism of emulsifying action may, however, be different than expected and also include formation of an amphiphilic helix. Gamma-1 led to the lowest initial and equilibrium values of interfacial tension. This correlated well with the lowest droplet size after production and during storage, and the no or little creaming observed for $\gamma 1$-stabilized $5 \mathrm{wt} . \%$ fish oil-in-water emulsion (also when compared to casein-stabilized emulsions). Moreover, the oxidative stability of the emulsions was affected by the type of emulsifier peptide used, which could not be only explained by their different in vitro antioxidant properties. For instance, 5wt.\% fish oil-in-water emulsions stabilized either with $\gamma 1$ or casein showed similar oxidative stability according to Oxygraph results. On the other hand, ESR results suggested a more advanced oxidation in emulsions stabilized with $\beta 1, \gamma 1$ and $\gamma 2$ peptides, which could explain the degradation of PBN spin adducts and the appearance of non-enzymatic browning.

\section{ACKNOWLEDGEMENTS}

The authors acknowledge Emma Møller Husted and Merve Atak for their help developing the bioinformatics algorithms and optimization of the sonication method, respectively. This work was supported by Innovation Fund Denmark (PROVIDE project: Protein valorization through informatics, hydrolysis, and separation). 


\section{REFERENCES}

626

627

628

629

630

631

632

633

634

635

636

637

638

639

640

641

642

643

644

645

646

647

648

Agyei, D., Tsopmo, A., \& Udenigwe, C. C. (2018). Bioinformatics and peptidomics approaches to the discovery and analysis of food-derived bioactive peptides. Analytical and Bioanalytical Chemistry, 410(15), 3463-3472.

Alting, A. C., Pouvreau, L., Giuseppin, M. L. F., \& van Nieuwenhuijzen, N. H. (2011).

Potato proteins. Handbook of Food Proteins, In G. O. Phillips, P. A. Williams (Eds.)

Woodhead publishing (pp. 316-334). Cambridge: Woodhead Publishing Limited.

Andersen, M. L., \& Skibsted, L. H. (2008). ESR Spectroscopy for the Study of Oxidative Processes in Food and Beverages. In Modern Magnetic Resonance (pp. 18611866). Dordrecht: Springer Netherlands.

Barlow, D. J., \& Thornton, J. M. (1987). Helix geometry in proteins. Journal of Molecular Biology, 201(201), 601-619.

Bateman, A., Martin, M. J., O'Donovan, C., Magrane, M., Alpi, E., Antunes, R., ... Zhang, J. (2017). UniProt: The universal protein knowledgebase. Nucleic Acids Research, 45(1), D158-D169.

Bauw, G., Nielsen, H. V., Emmersen, J., Nielsen, K. L., Jørgensen, M., \& Welinder, K.

G. (2006). Patatins, Kunitz protease inhibitors and other major proteins in tuber of potato cv. Kuras. Febs Journal, 273(15), 3569-3584.

Berton-Carabin, C. C., Ropers, M. H., \& Genot, C. (2014). Lipid Oxidation in Oil-inWater Emulsions: Involvement of the Interfacial Layer. Comprehensive Reviews in Food Science and Food Safety, 13(5), 945-977.

Cheng, Y., Chen, J., \& Xiong, Y. L. (2014). Interfacial adsorption of peptides in oil-inwater emulsions costabilized by tween 20 and antioxidative potato peptides. Journal of Agricultural and Food Chemistry, 62(47), 11575-11581. 
Cheng, Y., Chen, J., \& Xiong, Y. L. (2010). Chromatographic separation and tandem

650 MS identification of active peptides in potato protein hydrolysate that inhibit autoxidation of 651 soybean oil-in-water emulsions. Journal of Agricultural and Food Chemistry, 58(15), 88256528832.

Cheng, Y., Xiong, Y. L., \& Chen, J. (2010). Antioxidant and emulsifying properties of 654 potato protein hydrolysate in soybean oil-in-water emulsions. Food Chemistry, 120(1), 101655108. secondary structures are influenced by the protein structural class. Biochemical and Biophysical Research Communications, 342(2), 441-451.

Dexter, A. F., \& Middelberg, A. P. J. (2008). Peptides as functional surfactants. 660 Industrial and Engineering Chemistry Research, 47(17), 6391-6398. moment: A measure of the amphiphilicity of a helix. Nature, 299(5881), 371-374. structure-activity relationships of peptide emulsifiers and foaming agents. International 667 Journal of Biological Macromolecules, 12: 118-124. 
Fauchere, J. L., \& Pliska, V. (1983). Hydrophobic parameters-pi of amino-acid side-

chains from the partitioning of n-acetyl-amino-acid amides. European Journal of Medicinal

674

675

Chemistry, 18(4), 369-375.

García-Moreno, P. J., Batista, I., Pires, C., Bandarra, N. M., Espejo-Carpio, F. J., Guadix, A., \& Guadix, E. M. (2014). Antioxidant activity of protein hydrolysates obtained from discarded Mediterranean fish species. Food Research International, 65, 469-476.

García-Moreno, P. J., Guadix, A., Guadix, E. M., \& Jacobsen, C. (2016). Physical and oxidative stability of fish oil-in-water emulsions stabilized with fish protein hydrolysates. Food Chemistry, 203, 124-135.

Gautier, R., Douguet, D., Antonny, B., \& Drin, G. (2008). HELIQUEST: a web server to screen sequences with specific $\alpha$-helical properties. Bioinformatics, 24(18), 2101-2102.

Ghelichi, S., Sørensen, A. -. M., García-Moreno, P. J., Hajfathalian, M., \& Jacobsen, C. (2017). Physical and oxidative stability of fish oil-in-water emulsions fortified with enzymatic hydrolysates from common carp (cyprinus carpio) roe. Food Chemistry, 237, 1048-1057.

Grommers, H. E., \& van der Krogt, D. A. (2009). Potato Starch: Production, Modifications and Uses. In G. O. Phillips, P. A. Williams (Eds.) Woodhead publishing (pp. 511-539). Cambridge: Woodhead Publishing Limited.

Jørgensen, M., Stensballe, A., \& Welinder, K. G. (2011). Extensive post-translational processing of potato tuber storage proteins and vacuolar targeting. Febs Journal, 278(21), 4070-4087.

Jørgensen, M., Welinder, K. G., \& Bauw, G. (2006). Molecular Properties and Activities of Tuber Proteins from Starch Potato Cv. Kuras. Journal of Agricultural and Food Chemistry, 54(54), 9389-9397. 
Jung, J.-M., Gunes, D. Z., \& Mezzenga, R. (2010). Interfacial activity and interfacial

696

697

698

699

700

701

702

703

704

705

706

707

708

709

710

711

712

713

714

715

716

717

718

719

shear rheology of native b-lactoglobulin monomers and their heat-induced fibers. Langmuir:

The ACS Journal of Surfaces and Colloids, 26(18), 15366-15375.

Kudo, K., Onodera, S., Takeda, Y., Benkeblia, N., \& Shiomi, N. (2009). Antioxidative activities of some peptides isolated from hydrolyzed potato protein extract. Journal of Functional Foods, 1(2), 170-176.

Kyte, J., \& Doolittle, R. F. (1982). A simple method for displaying the hydropathic character of a protein. Journal of Molecular Biology, 157(1), 105-132.

Liu, Y. W., Han, C. H., Lee, M. H., Hsu, F. L., \& Hou, W. C. (2003). Patatin, the tuber storage protein of potato (Solanum tuberosum L.), exhibits antioxidant activity in vitro. Journal of Agricultural and Food Chemistry, 51, 4389-4393.

Lu, F. S. H., Nielsen, N. S., Baron, C. P., Diehl, B. W. K., \& Jacobsen, C. (2013). Impact of primary amine group from aminophospholipids and amino acids on marine phospholipids stability: Non-enzymatic browning and lipid oxidation. Food Chemistry, 141(2), 879-888.

McClements, D. J. (2005). Food emulsions - Principles, practices, and techniques. Boca Raton: CRC Press.

Mozuraityte, R., Rustad, T., \& Storrø, I. (2008). The role of iron in peroxidation of polyunsaturated fatty acids in liposomes. Journal of Agricultural and Food Chemistry, 56(2), 537-543.

Mozuraityte, R., Kristinova, V., Rustad, T., \& Storrø, I. (2016). The role of iron in peroxidation of PUFA: Effect of $\mathrm{pH}$ and chelators. European Journal of Lipid Science and Technology, 118(4), 658-668.

Nwachukwu, I. D., \& Aluko, R. E. (2019). Structural and functional properties of food protein-derived antioxidant peptides. Journal of Food Biochemistry, e12761. 
O'Loughlin, I. B., Murray, B. A., FitzGerald, R. J., Brodkorb, A., \& Kelly, P. M.

721

722

723

724

725

726

727

728

729

730

731

732

733

734

735

736

737

738

739

740

741

742

743

744

(2014). Pilot-scale production of hydrolysates with altered bio-functionalities based on thermally-denatured whey protein isolate. International Dairy Journal, 34(1), 146-152.

O'Sullivan, J., Murray, B., Flynn, C., \& Norton, I. (2015). Comparison of batch and continuous ultrasonic emulsification processes. Journal of Food Engineering, 167, 114-121.

Pots, A. M., De Jongh, H. H. J., Gruppen, H., Hamer, R. J., \& Voragen, A. G. J. (1998). Heat-induced conformational changes of patatin, the major potato tuber protein. European Journal of Biochemistry, 252(1), 66-72.

Pouvreau L, Gruppen H, Piersma SR, van den Broek LAM, van Koningsveld GA \& Voragen AGJ (2001) Relative abundance and inhibitory distribution of protease inhibitors in potato juice from cv. Elkana. J Agric Food Chem. 49(6), 2864-2874.

Romero, A., Beaumal, V., David-Briand, E., Cordobés, F., Guerrero, A., \& Anton, M. (2011). Interfacial and oil/water emulsions characterization of potato protein isolates. Journal of Agricultural and Food Chemistry, 59(17), 9466-9474.

Schmidt, J. M., Damgaard, H., Greve-Poulsen, M., Larsen, L. B., \& Hammershøj, M. (2018). Foam and emulsion properties of potato protein isolate and purified fractions. Food Hydrocolloids, 74, 367-378.

Schmidt, J. M. (2016). PhD Thesis: Purification and functional properties of potato protein fractions.

Schröder, A., Berton-Carabin, C., Venema, P., \& Cornacchia, L. (2017). Interfacial properties of whey protein and whey protein hydrolysates and their influence on $\mathrm{O} / \mathrm{W}$ emulsion stability. Food Hydrocolloids, 73, 129-140.

Sun, Y., Jiang, L., \& Wei, D. (2013). Partial characterization, in vitro antioxidant and antiproliferative activities of patatin purified from potato fruit juice. Food and Function, 4(10), 1502-1511. 
Udenigwe, C. C., Udechukwu, M. C., Yiridoe, C., Gibson, A., \& Gong, M. (2016).

Antioxidant mechanism of potato protein hydrolysates against in vitro oxidation of reduced glutathione. Journal of Functional Foods, 20, 195-203.

Van Koningsveld, G. A., Walstra, P., Voragen, A. G. J., Kuijpers, I. J., Van Boekel, M.

A. J. S., \& Gruppen, H. (2006). Effects of protein composition and enzymatic activity on formation and properties of potato protein stabilized emulsions. Journal of Agricultural and Food Chemistry, 54(17), 6419-6427.

Velasco, J., Andersen, M. L., \& Skibsted, L. H. (2005). Electron spin resonance spin trapping for analysis of lipid oxidation in oils: Inhibiting effect of the spin trap $\alpha$-phenyl-Ntert-butylnitrone on lipid oxidation. Journal of Agricultural and Food Chemistry, 53(5), 13281336.

Wang, L. L., \& Xiong, Y. L. (2005). Inhibition of lipid oxidation in cooked beef patties by hydrolyzed potato protein is related to its reducing and radical scavenging ability. Journal of Agricultural and Food Chemistry, 53(23), 9186-9192.

Waterhouse, A., Bertoni, M., Bienert, S., Studer, G., Tauriello, G., Gumienny, R., ... Schwede, T. (2018). SWISS-MODEL: Homology modelling of protein structures and complexes. Nucleic Acids Research, 46(1), W296-W303.

Wijeyesakere, Sanjeeva J., Rudy J. Richardson, and Jeanne A. Stuckey (2014). Crystal structure of patatin-17 in complex with aged and non-aged organophosphorus compounds. PloS one 9.9: e108245.

Zhou, L., \& Elias, R. J. (2012). Factors Influencing the Antioxidant and Pro-Oxidant Activity of Polyphenols in Oil-in-Water Emulsions. Journal of Agricultural and Food Chemistry, 60(11), 2906-2915. 
Table 2. Values of $\mathrm{pH}$, droplet size, zeta potential and observations on creaming of the emulsions

\begin{tabular}{|c|c|c|c|c|c|c|c|}
\hline \multirow{2}{*}{ Emulsion } & \multirow{2}{*}{ Solubility* } & \multirow[b]{2}{*}{$\mathrm{pH}$} & \multirow{2}{*}{$\begin{array}{c}\text { Zeta } \\
\text { potential } \\
(\mathrm{mV})\end{array}$} & \multicolumn{2}{|c|}{$\mathrm{D}_{4,3}(\mu \mathrm{m})$} & \multirow{2}{*}{$\begin{array}{l}\text { Observations } \\
\text { after production }\end{array}$} & \multirow{2}{*}{$\begin{array}{l}\text { Observations after } \\
2 \text { days at } 50^{\circ} \mathrm{C}\end{array}$} \\
\hline & & & & Day 0 & Day 2 at $50^{\circ} \mathrm{C}$ & & \\
\hline$\alpha 1$ & Cloudy & 6.5 & $-37.1 \pm 2.6^{d}$ & $7.455 \pm 1.056^{d}$ & $7.922 \pm 0.170^{\mathrm{c}, \mathrm{ns}}$ & Little creaming & $\begin{array}{l}\text { Middle-high } \\
\text { creaming }\end{array}$ \\
\hline$\alpha 2$ & Cloudy & 6.3 & $-51.0 \pm 4.2^{\mathrm{b}, \mathrm{c}}$ & $2.606 \pm 0.033^{b}$ & $4.532 \pm 0.269^{\mathrm{b}, *}$ & Little creaming & $\begin{array}{l}\text { Middle-high } \\
\text { creaming }\end{array}$ \\
\hline$\alpha 3$ & Soluble & 5.7 & $-13.9 \pm 7.0^{\mathrm{e}}$ & $0.842 \pm 0.128^{a}$ & n.m. & No creaming & Totally separated \\
\hline$\beta 1$ & Soluble & 6.3 & $-55.1 \pm 2.7^{\mathrm{a}, \mathrm{b}}$ & $4.545 \pm 0.163^{\mathrm{c}}$ & $15.893 \pm 2.813^{\mathrm{d},{ }^{*}}$ & No creaming & $\begin{array}{c}\text { Severe creaming } \\
\text { with brown aqueous } \\
\text { phase }\end{array}$ \\
\hline y1 & Soluble & 6.3 & $-62.4 \pm 3.5^{\mathrm{a}}$ & $0.516 \pm 0.010^{\mathrm{a}}$ & $0.518 \pm 0.011^{\mathrm{a}, \mathrm{ns}}$ & No creaming & $\begin{array}{l}\text { No or very little } \\
\text { creaming with brown } \\
\text { aqueous phase }\end{array}$ \\
\hline $\mathrm{y}^{2}$ & Soluble & 6.4 & $-61.6 \pm 2.4^{a, b}$ & $8.267 \pm 0.079^{d}$ & 8.0 & No creaming & $\begin{array}{l}\text { Severe creaming } \\
\text { with brown aqueous } \\
\text { phase }\end{array}$ \\
\hline Casein & Soluble & 6.6 & $-41.8 \pm 1.9^{\mathrm{c}, \mathrm{d}}$ & $1.337 \pm 0.101^{\mathrm{a}}$ & $17.462 \pm 0.201^{\mathrm{d}, *}$ & No creaming & $\begin{array}{l}\text { Middle-high } \\
\text { creaming }\end{array}$ \\
\hline Potato & Soluble & 6.9 & $-27.3 \pm 0.9$ & $57.076 \pm 28.245$ & n.m. & Severe creaming & $\begin{array}{l}\text { Totally separated } \\
\text { and slight brown } \\
\text { aqueous phase }\end{array}$ \\
\hline
\end{tabular}

*Solubility of peptides in $10 \mathrm{mM}$ sodium acetate $-10 \mathrm{mM}$ imidazole buffer (pH 7). Soluble: totally soluble; cloudy: not totally soluble. Concentration tested: $0.2 \mathrm{wt} . \%$.

n.m.: emulsions were totally separated and droplet size could not be measured at day 2 .

For each column, different letters indicate significant differences between peptide samples $(\mathrm{p}<0.05)$.

Significant differences between day 1 and 2 are indicated by either *: significantly different $(\mathrm{p}<0.05)$, or ns: not significantly different. 


\section{TABLES}

Table 1. Properties of potato peptides predicted by bioinformatics to have emulsifying activity

\begin{tabular}{|c|c|c|c|c|c|c|c|c|c|c|c|}
\hline Peptide & Sequence & Score* & $\begin{array}{c}\text { Accession } \\
\text { number }\end{array}$ & Position & $\begin{array}{c}\text { Number } \\
\text { of } \\
\text { residues }\end{array}$ & $\begin{array}{l}\text { a-helical } \\
\text { content }^{\star \star}\end{array}$ & $\begin{array}{l}\beta \text {-strand } \\
\text { content }^{\star \star}\end{array}$ & $\begin{array}{c}\text { Purity }^{\star \star *} \text {, } \\
\%\end{array}$ & $\begin{array}{l}\text { Mw, } \\
\text { g/mol }\end{array}$ & $\mathbf{p l}^{\star \star \star \star \star}$ & $\begin{array}{c}\text { Net } \\
\text { charge } \\
(\mathrm{pH} 7)\end{array}$ \\
\hline$\alpha 1$ & AKDIVPFYFEHGPHIFNYSGSIIGPMYDG & 35.9 & P15477 & 99 & 29 & $52 \%$ & $0 \%$ & 98.7 & 3272.6 & 5.1 & -1.8 \\
\hline$\alpha 2$ & HHFVTHTSNGARYEFNLVDGAVATVGDPA & 36.4 & P15477 & 197 & 29 & $3 \%$ & $45 \%$ & 937 & 3083.3 & 5.8 & -1.7 \\
\hline$\alpha 3$ & KPVSKDSPETYEEALKRFAKLLS & 33.3 & $\begin{array}{l}\text { P15477 } \\
\text { P11768 } \\
\text { Q42502 } \\
\text { Q3YJT3 }\end{array}$ & $\begin{array}{l}352 \\
352 \\
352 \\
340\end{array}$ & 23 & $57 \%$ & $9 \%$ & 72.4 & 2636.9 & 9.4 & 1 \\
\hline$\beta 1$ & LRVQENALTGTTTKADDASEANMELLVQV & 42.2 & Q3YJT5 & 318 & 29 & $34 \%$ & $10 \%$ & 70.3 & 3118.4 & 3.8 & -3 \\
\hline y1 & GIKGIIPAIILEFLEGQLQEVDNNKDAR & 51.9 & P11768 & 38 & 28 & $72 \%$ & $0 \%$ & 99.4 & 3094.5 & 4.2 & -2 \\
\hline $\mathrm{y}^{2}$ & ANMILLVQVGENLLKKSVSEDNHETYE & 45.3 & Q3YJS9 & 325 & 27 & $63 \%$ & $7 \%$ & 90.5 & 3074.4 & 4.2 & -2.9 \\
\hline
\end{tabular}

*Score of mean hydrophobic vector.

**Fraction of residues located in a given secondary structure conformation (within the native protein) as implied by homology modelling using Patatin-17 as structural template.

*** Purity of the synthetic peptides used as received from Chinapeptides.

$* * * *$ pI and net charge were calculated by using peptide property calculator from Innovagen (Innovagen AB, Lund, Sweden) 


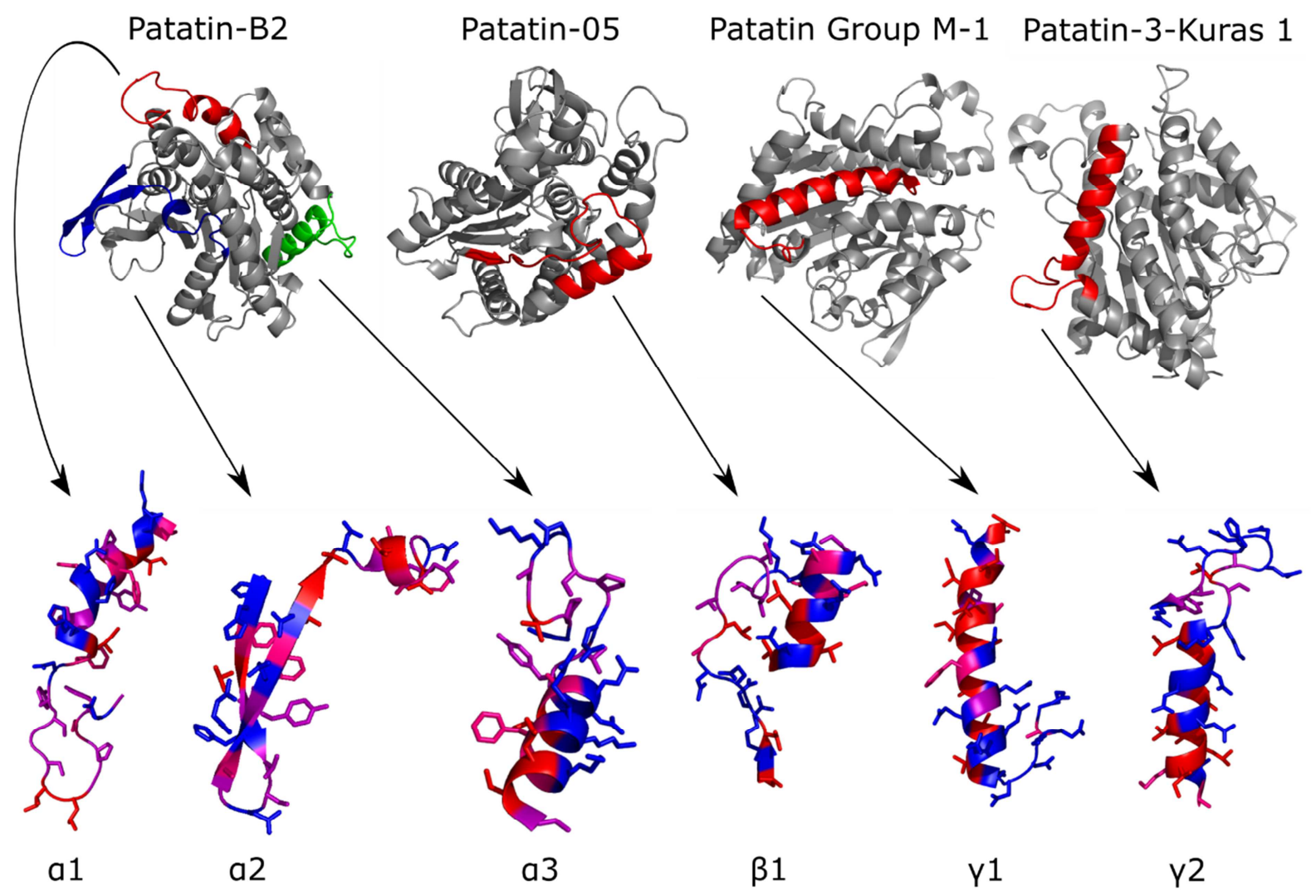

Fig. 1. Localization of predicted emulsifier peptides based on template homology modelling using SwissProt and visualized in PyMOL. Models are made using the identified patatin isoform for the predicted peptides (Table 1) using the X-ray structure of Patatin-17 (SMTL ID 4pka.1.A) as template. Localization of $\alpha 1$ (red), $\alpha 2$ (blue), and $\alpha 3$ (green) in Patatin-B2 (UniProt AC\# P15477), $\beta 1$ (red) in Patatin-05 (UniProt AC\# Q3YJT5), $\gamma 1$ (red) in Patatin Group M-1 (UniProt AC\# P11768), and $\gamma 2$ (red) in Probable inactive patatin-3-Kuras 1 (UniProt AC\# Q3YJS9). Beneath, secondary structure of predicted peptides (within the parent proteins) according to the models. Backbone and side chain and coloring according to the SwissModel hydrophobicity color scale (most hydrophobic residues in red and most hydrophilic residues in blue). 


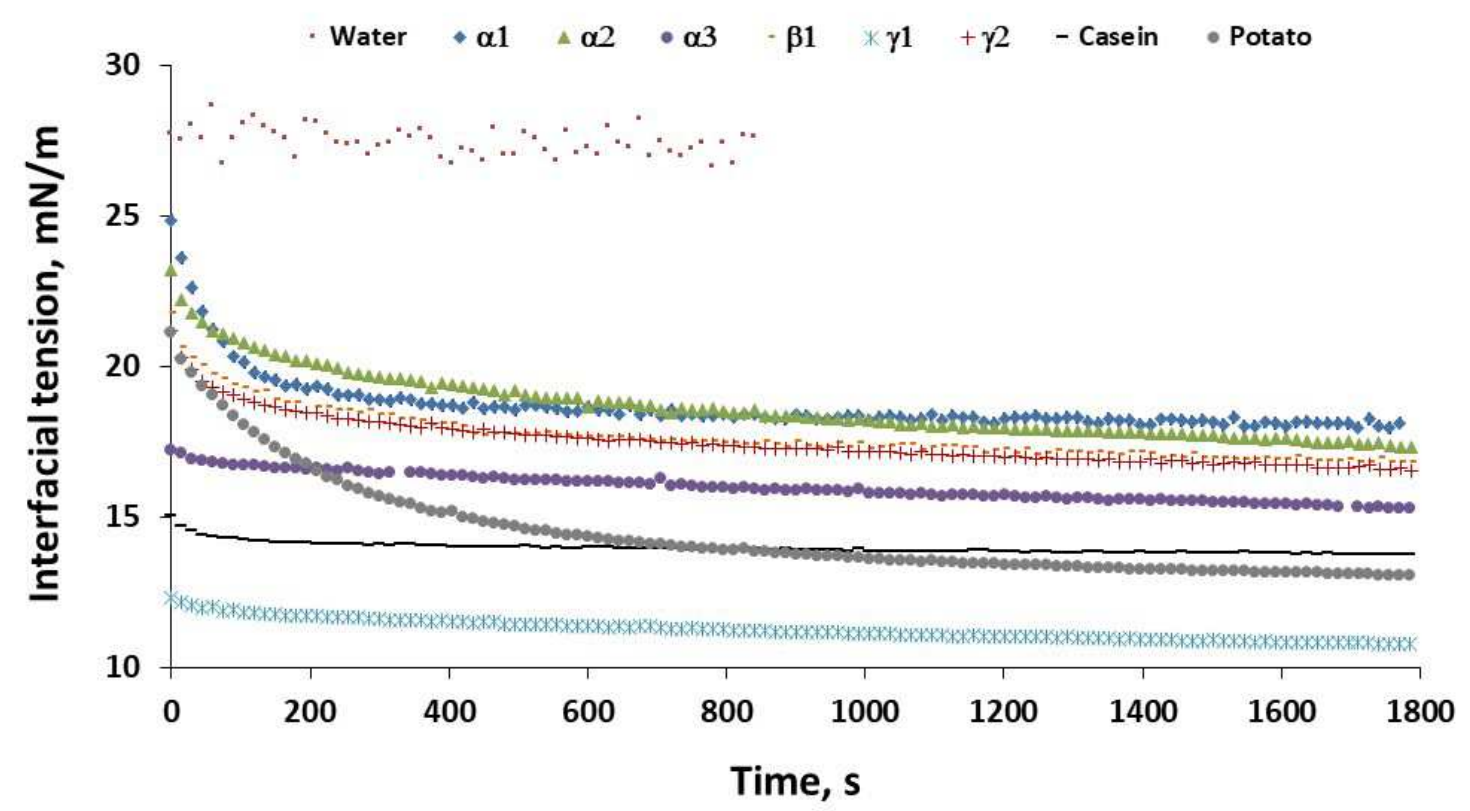

Fig. 2. Interfacial tension at the fish oil-aqueous phase interface, with the aqueous phase containing $0.1 \mathrm{wt}$. $\%$ peptides in $10 \mathrm{mM}$ sodium acetate - $10 \mathrm{mM}$ imidazole buffer $(\mathrm{pH} 7)$. 
a)

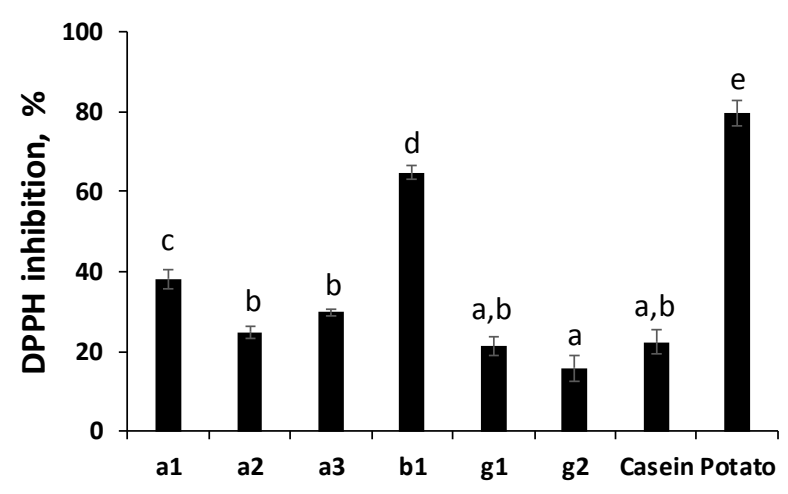

b)

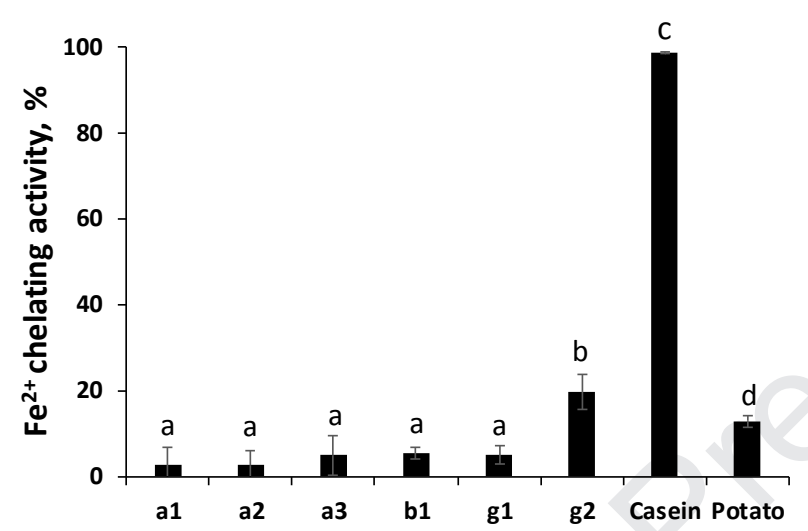

c)

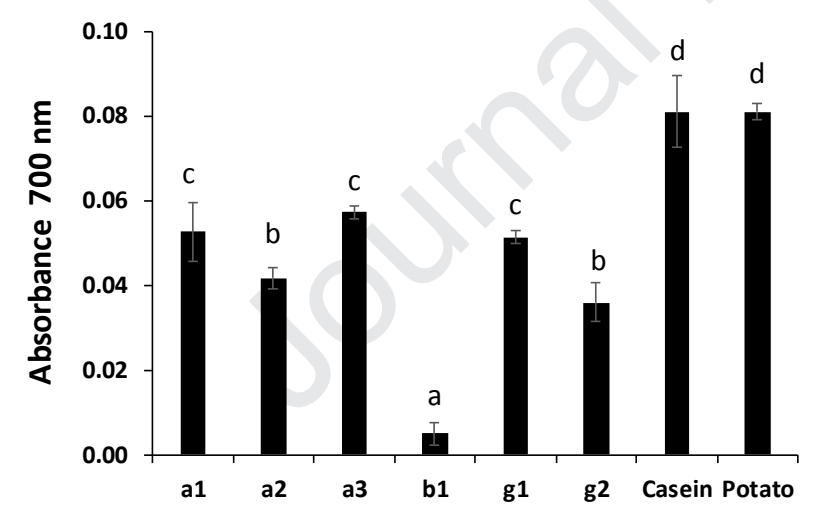

Fig. 3. In vitro antioxidant capacity of synthetic potato peptides ( $0.2 \mathrm{wt} . \%$ at $\mathrm{pH} 7)$ : a) DPPH radical scavenging activity, b) $\mathrm{Fe}^{2+}$ chelating activity, and c) $\mathrm{Fe}^{3+}$ reducing power.

Different letters indicate significant differences between samples $(\mathrm{p}<0.05)$

Peptides names with $\mathrm{a}, \mathrm{b}$ and $\mathrm{g}$ denotes $\alpha, \beta$ and $\mathrm{\gamma}$, respectively. 
a)

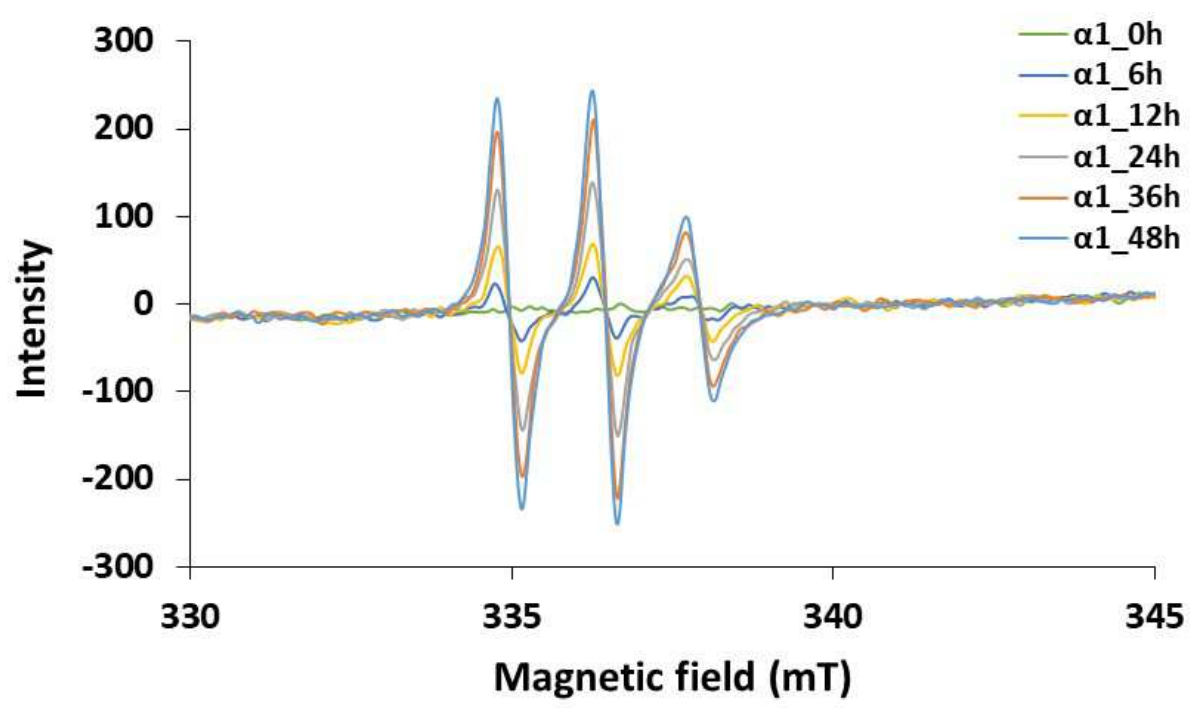

b)

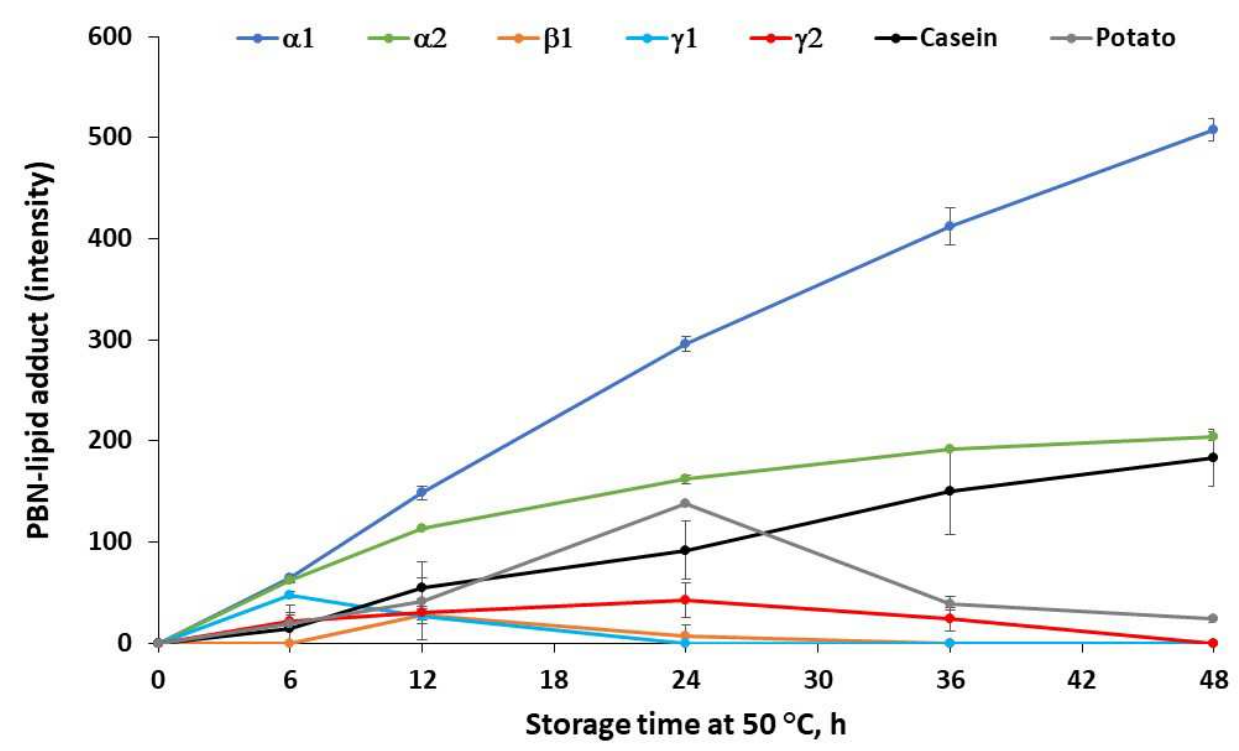

Fig. 4. a) Evolution of peak-to-peak amplitude of PBN-ESR spectra with storage time at 50 ${ }^{\circ} \mathrm{C}$ for the emulsion stabilized with synthetic potato peptide $\alpha 1$. b) PBN-lipid derived spin adducts generation resulting from the oxidation of $5 \mathrm{wt} \%$ fish oil-in-water emulsions stabilized with synthetic potato peptides during storage at $50{ }^{\circ} \mathrm{C}$ in the dark.

ESR results for emulsion stabilized with $\alpha 3$ were not shown in Fig. 4 b since it totally separated after 6 $\mathrm{h}$ at $50{ }^{\circ} \mathrm{C}$ giving no intensity when measured at time zero. 
a)

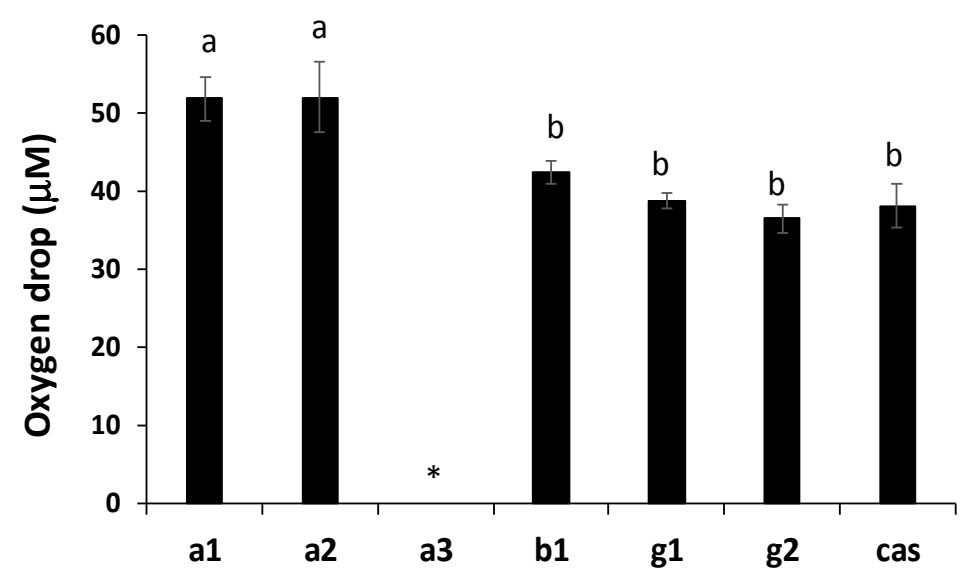

b)

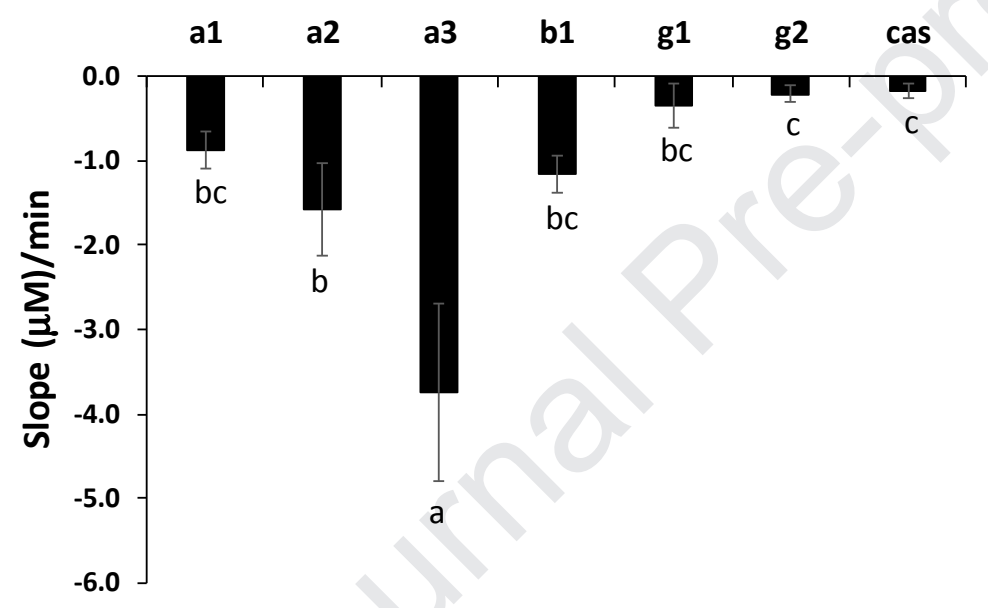

Fig. 5. a) Drop in oxygen concentration, and b) net oxygen uptake rate in emulsion stabilized with synthetic potato peptides during iron-mediated oxidation $\left(45 \mu \mathrm{M}\right.$ of $\left.\mathrm{Fe}^{2+}\right)$

*The determination of oxygen drop in this emulsion was not possible due to the shape of the curve when compared to the rest of the curves obtained (see Fig. 6S in the Supplementary Material).

Different letters indicate significant differences between samples $(\mathrm{p}<0.05)$

Peptides names with $\mathrm{a}, \mathrm{b}$ and $\mathrm{g}$ denotes $\alpha, \beta$ and $\mathrm{\gamma}$, respectively. 


\section{Highlights}

2

- Bioinformatics to identify emulsifying peptides embedded in potato protein

3

- Synthetic peptides with different conformation at the o/w interface were tested

$4 \quad-\quad \gamma 1$ had superior emulsifying activity than the rest of the peptides and casein

5

- The type of peptide used affected the chemical stability of fish o/w emulsions 


\section{Declaration of interests}

$\bigotimes$ The authors declare that they have no known competing financial interests or personal relationships that could have appeared to influence the work reported in this paper.

$\square$ The authors declare the following financial interests/personal relationships which may be considered as potential competing interests: 